\title{
Assessment Methods of Small Watershed Ecosystem Health
}

\author{
Wenbin Pan, Hui Huang, Pengcheng Yao, Peng Zheng* \\ College of Environment and Resources, Fuzhou University, Fuzhou, Fujian 350116, China
}

Received: 9 April 2020

Accepted: 18 July 2020

\begin{abstract}
The assessment of watershed ecosystem health promotes the construction of ecological civilisation in China, and assessment results are an important basis for watershed planning and management. At present, research on and application of small watershed ecosystem health assessment in China are deficient. Thus, small watershed protection and management in China are restricted. The research object of this study is a small watershed of Changqing River in Yongtai County of Fuzhou City. Using satellite image data, digital elevation data as well as field and monitoring data combined with $3 \mathrm{~S}$ technology, the health status of the small watershed ecosystem was evaluated by three assessment systems consisting of remote sensing data, measured survey data and multi-source data. The watershed ecosystem health status was quantitatively analysed, and a comparative analysis with the results of different evaluation methods was conducted. Results show that, in general, the comprehensive indexes of ecosystem health obtained by the three evaluation methods are 70.29, 77.68 and 63.87 . The evaluation results support the notion that the research status of the watershed ecosystem is satisfactory. The overall ecosystem health status of the high mountains sub-watershed in the northwest and in the southwest of the watershed is relatively acceptable but that of the middle and lower reaches is relatively poor. Finally, the evaluation results of the three methods were compared, and their differences were analysed, it can provide a basic idea for the ecosystem health evaluation of the small watershed.
\end{abstract}

Keywords: ecological health, evaluation method, small watershed, multi-source data

\section{Introduction}

Watershed touches all parts of the natural environment and all aspects of human life and culture. It is characterized by a continuous flow of water and is an open and dynamic natural ecosystem, which constantly accepts materials brought on by nature and human activities. The watershed ecosystem has various

*e-mail: PengZheng@fzu.edu.cn ecological functions because of its 'inclusive' nature. In a relatively healthy watershed, its ecosystem structure (form structure and nutrition structure) is reasonable. The function (energy flow, material circulation and information transmission) is perfect, with strong antiinterference ability; it contains great economic value and serves as the basis of human social development [1-4]. In order to maintain the normal function of the river, the watershed can accept a certain amount of pollutants and reduce pollution to the river environment through the self-purification function [5-8]. However, the self-regulation ability of the watershed ecosystem is 
limited, especially if its system structure and function are destroyed beyond the limit [9-10].

Watershed ecosystem health assessment aims not only to study and monitor the ecological process of different types of ecosystems in the watershed, but also to monitor the environmental quality from the landscape and watershed scales. The global positioning system (GPS), remote sensing (RS), geographic information system (GIS), landscape ecology principles and macro technical means are closely coordinated with the ground investigation and study, and the functional processes are explained through the change in landscape structure [11-14]. The best watershed ecosystem health assessment is a comprehensive study that combines microscopic and macroscopic approaches [15-18]. Specific methods include indicator species evaluation and indicator system evaluation. Studies on indicator species for ecosystem health have made great progress and have become the basic method of ecosystem health research [19-23]. However, some problems still exist. For example, the selection criteria of indicator species are unclear, and some species are unsuitable. The indicator system method is based on indicators that can accurately reflect the ecological status information of the watershed [24]. However, the method does not use a single indicator because information in a single indicator cannot represent the ecological status of the entire watershed; moreover, accurately evaluating the ecological status of the watershed requires a complex combination of many indicators [25]. In the study of watershed ecosystem health assessment, the selection of indicator species and indicators is critical, and their sensitivity and reliability should be considered comprehensively, that is, the strength of their indicator effect on watershed natural ecosystem health should be determined [26-27].

Globally, studies on the health evaluation of natural ecosystems in small watersheds are relatively few. Finding suitable species is difficult because of the limited biological species in small watersheds. Thus, the indicator species method is rarely used compared with the more common indicator system method. The advantage of the watershed ecosystem evaluation index system is that it can integrate ecological, human and economic indicators, reveal the watershed ecological status from different aspects and then more accurately and comprehensively reflect the watershed ecosystem status [28-30]. Over the years, the application of $3 \mathrm{~S}$ technology in watershed ecosystem health assessment research has become increasingly extensive. The term "3S technology" is a collective term for RS, GIS and GPS, which are the three key technologies of obtaining spatial information, storage management, analysis and application. The data acquisition channels have become increasingly diversified, and the selection of indicators is more abundant. In $3 \mathrm{~S}$ technology, satellite remote sensing data are used; data obtained through ArcGIS, ENVI and other related software are extracted and analysed; required data information are obtained; and data obtained through other approaches are combined to build a comprehensive evaluation model for evaluating the health status of the regional ecosystem. The advantage of this technology is the high availability of data, which can facilitate an objective evaluation of the region. A large number of field monitoring and investigation is not required, and the traffic conditions of the study area may not be considered. For the same evaluation area, basic evaluation units of different scales can be determined as required, and the spatial distribution map of the regional ecosystem health can be drawn. The $3 \mathrm{~S}$ and other new technologies and methods [31-32] are fast, accurate and economically feasible for the quantitative assessment of watershed ecosystem health and the establishment of relevant models, which will greatly promote the development of watershed ecosystem health assessment.

In recent years, the research on the evaluation of ecosystem health in river watersheds have focused on constructing an evaluation index system, but many studies are limited to using one type of system to evaluate the health of river watershed ecosystems. The index system has some differences in the assessment of watershed ecosystem health. On the basis of remote sensing data, measured survey data and multi-source data, the current study introduces three methods to construct different evaluation systems for the comprehensive evaluation of ecosystem health in the Changqing Watershed. Among them, multi-source data are a combination of remote sensing data and measured survey data. This study evaluated the ecosystem health of a small watershed, quantitatively analysed the ecosystem health of the Changqing Watershed and compared the results of different evaluation methods using the evaluation system composed of remote sensing data, measured survey data and multi-source data. The results provide reference suggestions for the construction of improved ecosystem health assessment systems for monitoring small watersheds.

\section{Materials and Methods}

\section{Study Area}

The study was carried out in Changqing, a famous national, historical and cultural town. Changqing is located 65 kilometres to the west of Yongtai County, Fuzhou City, Fujian Province, with a total area of 165 square kilometres. The terrain of the Changqing Watershed is corridor valley, which belongs to the hilly area. It is located in the northeast extension of the Daiyun Mountains, with the terrain inclined from northwest to southeast. The main landforms in the watershed are mountains, valleys and hills. Changqing River is the first-level tributary of Dazhangxi, which is the largest downstream tributary of the Minjiang River. It flows through Changqing Town and flows further into Dazhangxi in Songkou town, originating from Minqing 


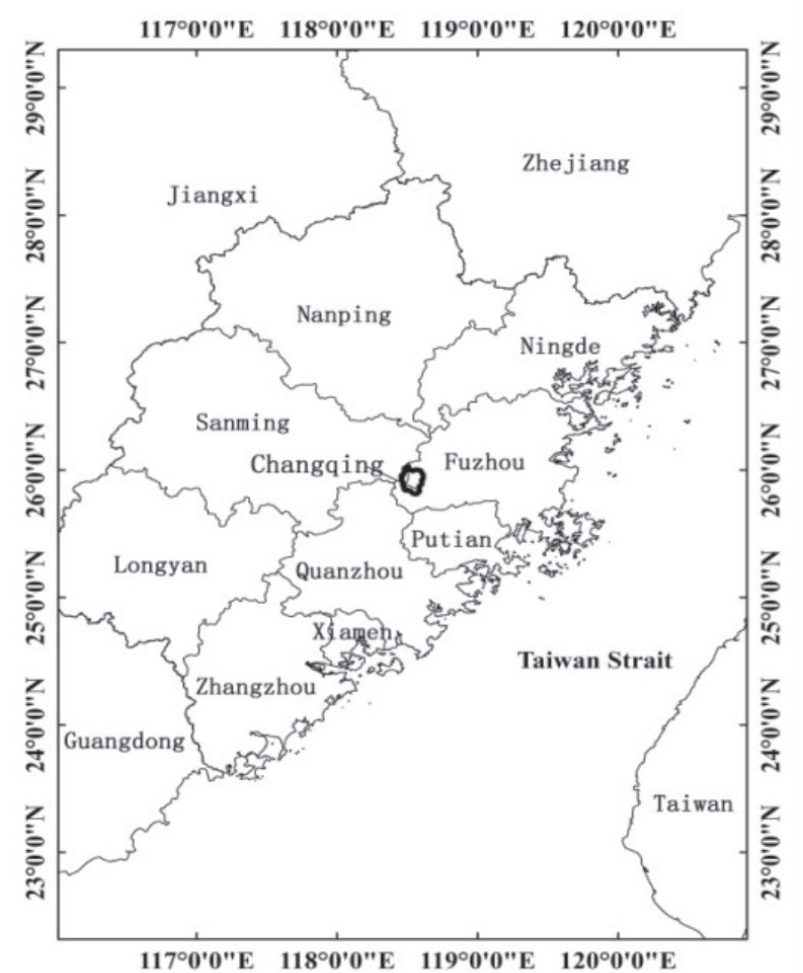

Fig. 1. Geographical location of the study area.

Chiyuan. The main river channel is $16.5 \mathrm{~km}$ long, with an average slope of $8.8 \%$ and a watershed area of up to $253 \mathrm{~km}^{2}$. The geographical location of the study area is shown in Fig. 1.

\section{Data Sources}

\section{Remote Sensing Image Data}

The required image data were obtained from http:// www.gscloud.cn. The satellite remote sensing image data of March 11, 2018 with low cloud cover were selected, with the orbit number of 119/42 and the image type of landsat8 OLI.

\section{DEM Data}

DEM data were obtained from http://www.gscloud. cn. This research is supported by the geospatial data cloud of Chinese Academy of Sciences. Based on Advanced Spaceborne Thermal Emission and Reflection Radiometer global digital elevation model V1, the resolution is $30 \mathrm{~m}$.

\section{Statistical Data}

The statistical data mainly include meteorological data, soil data and demographic and economic data. The meteorological data were acquired mainly through http://date.cma.cn and other relevant websites. The meteorological data involved in this study are mainly annual rainfall and monthly rainfall in the study area. The soil data were extracted from the second provincial soil census data of Fujian Province. The demographic and economic data were obtained through consulting the 'Yongtai Yearbook', the statistical bulletin and documents issued by relevant departments of Yongtai County.

\section{Survey and Measurement Data}

Nine sampling points were set in the study area, and GPS positioning was used during sampling, as shown in Fig. 2a).
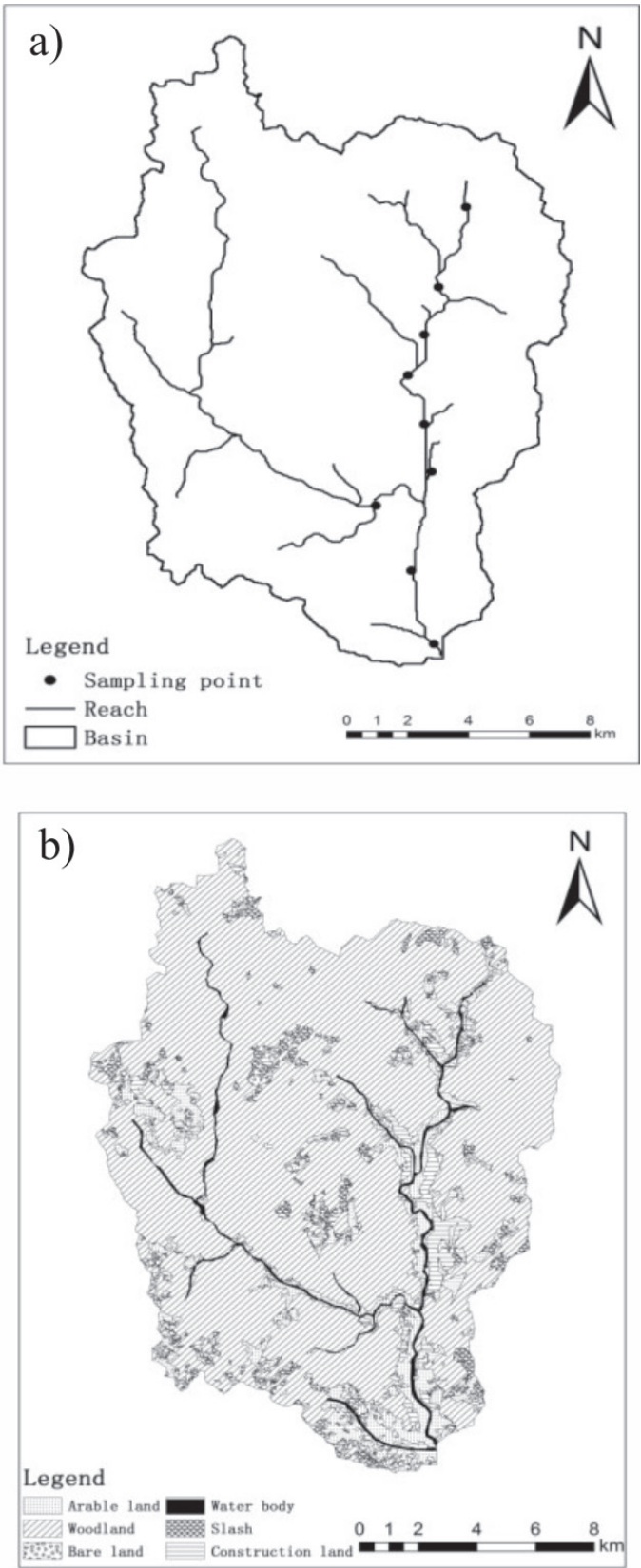

Fig. 2. Schematic diagram of sampling point a) and result diagram of land use classification $b$ ). 


\section{Physical and Chemical Indexes of Water Body}

In this study, the physical and chemical indexes of water body in the studied area were investigated and analyzed in August 2018. The water sample was collected in accordance with the 'Technical Specifications for Surface Water and Sewage Monitoring' (HJ/T 91-2002). Some physical and chemical indexes of the water body were investigated at the sampling point, and the values of each index were recorded. Three groups of parallel samples were obtained at each sampling point, with each group obtaining approximately $2 \mathrm{~L}$ water samples. Among them, water temperature $(\mathrm{T})$ was measured by a water temperature meter, $\mathrm{pH}$ was measured by a portable $\mathrm{pH}$ meter. Dissolved oxygen (DO), conductivity and total dispensed solids (TDS) were measured by using the Orion145a + tester. Turbidity and chlorophyll a were measured by Chlorotech121a handheld chlorophyll tester on site. Nine samples were collected for water sampling, and chemical oxygen demand by potassium permanganate method $\left(\mathrm{COD}_{\mathrm{Mn}}\right)$, total phosphorous (TP) and ammonia nitrogen $\left(\mathrm{NH}_{3}-\mathrm{N}\right)$ were detected in the laboratory. The detection data were mainly used in the assessment method of the watershed ecosystem based on the measured survey.

\section{Habitat Index/Biology}

In August 2018, according to field investigation and analysis, the upstream and downstream of the vertical sampling points were $200 \mathrm{~m}$, and the embankment revetment on both sides of the horizontal upper bank was $50 \mathrm{~m}$.

\section{Discharge of Industrial Pollution}

The data collected during the second national pollution survey included the discharge of pollutants from industrial enterprises and the cultivation of livestock and poultry. The second national pollution survey was conducted from May 2018 to August 2019. These data, including COD discharge, ammonia nitrogen discharge and annual wastewater discharge in the watershed, were used in the method of watershed ecosystem health assessment based on multi-source data in the current study.

\section{Remote Sensing Image Processing}

The FLAASH tool in ENVI 5.3 software was used for atmospheric correction. Data on the boundary of the Changqing Watershed were extracted by ArcGIS software and the digital elevation model (DEM) data of the study area. The land use of the Changqing Watershed was divided into six categories: construction land, bare land, woodland, arable land, water body and slash. The classification results are shown in Fig. 2b). Table 1 shows the data used in various evaluation methods and the difficulty of obtaining them. The classification accuracy evaluation indicators selected in this study mainly include Total accuracy, User accuracy and Kappa Coefficient, three indicators comprehensively indicate that the classification results have high credibility. See Appendix A for details.

\section{Watershed Ecosystem Health Assessment Based on Remote Sensing Data}

\section{Evaluation Unit Determination}

The basic units of the watershed ecosystem health assessment generally include administrative units and sub-watershed units. At present, no unified method is available at home and abroad for dividing the evaluation unit. The specific division method of the evaluation units is determined mainly by the objectives and tasks of the evaluation work. Considering the actual situation of the Changqing Watershed, this study finally selected six units as the basic evaluation units (Fig. 3), namely, source, upstream, midstream, downstream, tributary and alpine. The sub-watershed division of the Changqing Watershed was completed by SWAT. The DEM data were imported into SWAT, the boundary of

Table 1. Data acquisition difficulty.

\begin{tabular}{|c|c|c|c|c|}
\hline Evaluation method & Remote Sensing & Measured Survey & Multi-source & Data acquisition difficulty \\
\hline Remote sensing image data & $\sqrt{ }$ & & $\sqrt{ }$ & Easy \\
\hline DEM & $\sqrt{ }$ & & $\sqrt{ }$ & Easy \\
\hline Meteorological data & $\sqrt{ }$ & & $\sqrt{ }$ & Easy \\
\hline Demographic and economic data & $\sqrt{ }$ & & $\sqrt{ }$ & Easy \\
\hline Soil data & $\sqrt{ }$ & & $\sqrt{ }$ & Difficult \\
\hline Physical and chemical indexes of water body & & $\sqrt{ }$ & $\sqrt{ }$ & Difficult \\
\hline Habitat index & & $\sqrt{ }$ & $\sqrt{ }$ & Difficult \\
\hline Discharge of industrial pollution & & $\sqrt{ }$ & $\sqrt{2}$ Difficult \\
\hline
\end{tabular}




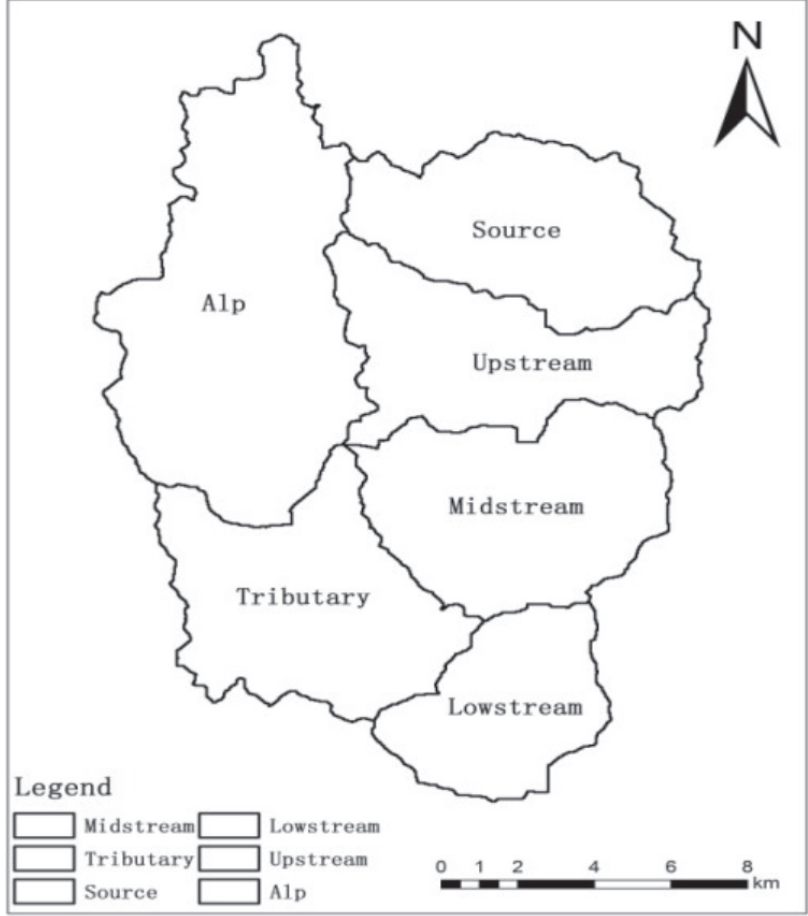

Fig. 3. Division of evaluation unit.

the study area was extracted, and the river network was generated. The SWAT divides the Changqing Stream into 31 sub-watersheds. On this basis, taking into account the actual situation of Changqing Watershed, this study finally selected the combination of topography and administrative division to redivide the 31 sub-watersheds, thus obtaining the above-mentioned six evaluation units. The source, upstream, midstream and downstream evaluation units are divided according to different reaches of Changqing Watershed, while the alpine evaluation unit is mainly divided according to the landform of Changqing Watershed. The evaluation unit named as alpine covers higher altitude area in the Changqing Watershed. Dividing into six evaluation units is more conducive to data acquisition and reduces the difficulty of acquiring data from field investigations.

\section{Construction of the Evaluation Index System}

We studied the assessment of ecosystem health in the river watershed, referred to relevant studies of other scholars and combined the information with the actual situation of Changqing Watershed [33]. Then, we referred to the indicators of the guidelines for technical assessment of ecosystem health in the river watershed issued by the Ministry of Environmental Protection of China. The pressure-state-response (P-S-R) model [34] was applied to the nine evaluation systems constructed by remote sensing indicators from the pressure layer, state layer and response layer, as shown in Table 2. This was done to quantitatively analyse and evaluate the ecological health of Changqing Watershed. The definition of each index is listed in Appendix B.

\section{Evaluation Criteria}

Index standardisation aims to eliminate the dimension. Different dimensions are determined due to the various types of indicators selected. The values of different indicators may differ by several orders of magnitude; thus, results may indicate that the data are incomparable and this can affect the evaluation. Many standardised methods are available, and the range normalisation method of min-max is selected for this work to standardise each index. The advantage of this method lies in its simplicity and feasibility. Through simple transformation, the value of each index can fall in the interval $(0,100)$. Each index is standardised through the calculation of the raster calculator in the spatial analysis module of ArcGIS, after which the standardised spatial distribution map of each index is obtained.

The evaluation index system has two different indexes. One is represented by habitat quality and water

Table 2. Watershed ecosystem health assessment index system.

\begin{tabular}{|c|c|c|}
\hline Target layer & Feature layer & Indicator layer X \\
\hline \multirow{9}{*}{$\begin{array}{l}\text { Watershed ecosystem health } \\
\text { assessment }\end{array}$} & \multirow{2}{*}{ Pressure } & Land reclamation index $\mathrm{X}_{1}$ \\
\hline & & Population interference index $\mathrm{X}_{2}$ \\
\hline & \multirow{6}{*}{ Status } & Total phosphorus load $\mathrm{X}_{3}$ \\
\hline & & Total nitrogen load $\mathrm{X}_{4}$ \\
\hline & & Habitat quality $\mathrm{X}_{5}$ \\
\hline & & Water conservation $\mathrm{X}_{6}$ \\
\hline & & Ecological elasticity $\mathrm{X}_{7}$ \\
\hline & & River network density $\mathrm{X}_{8}$ \\
\hline & Response & Soil sensitivity index $\mathrm{X}_{9}$ \\
\hline
\end{tabular}


Table 3. Weights of the indicators for ecosystem health assessment in the Changqing Watershed.

\begin{tabular}{|c|c|c|}
\hline $\begin{array}{c}\text { Indicator code } \\
\mathrm{X}_{\mathrm{i}}\end{array}$ & Indicator name & Weights $\mathrm{W}_{\mathrm{i}}$ \\
\hline $\mathrm{X}_{1}$ & Land reclamation index & 0.1104 \\
\hline $\mathrm{X}_{2}$ & $\begin{array}{c}\text { Population interference } \\
\text { index }\end{array}$ & 0.1071 \\
\hline $\mathrm{X}_{3}$ & Total phosphorus load & 0.0848 \\
\hline $\mathrm{X}_{4}$ & Total nitrogen load & 0.0892 \\
\hline $\mathrm{X}_{5}$ & Habitat quality & 0.1601 \\
\hline $\mathrm{X}_{6}$ & Water conservation & 0.1585 \\
\hline $\mathrm{X}_{7}$ & Ecological elasticity & 0.1582 \\
\hline $\mathrm{X}_{8}$ & River network density & 0.0293 \\
\hline $\mathrm{X}_{9}$ & Soil sensitivity index & 0.1024 \\
\hline
\end{tabular}

conservation, with the higher value indicating better regional ecology. Another one is represented by land reclamation rate and $\mathrm{TP}$ and total nitrogen load, with the larger value indicating worse regional ecology. We need to use different approaches to standardise the indicators because these types of indicators have completely opposite attributes.

$$
\begin{gathered}
X_{\mathrm{p}(\mathrm{x}, \mathrm{y})}=\frac{\mathrm{x}_{(\mathrm{x}, \mathrm{y})}-\mathrm{x}_{\min (\mathrm{y})}}{\mathrm{x}_{\max (\mathrm{y})}-\mathrm{X}_{\min (\mathrm{y})}} \times 100 \\
\mathrm{X}_{\mathrm{n}(\mathrm{x}, \mathrm{y})}=\frac{\mathrm{x}_{(\mathrm{x}, \mathrm{y})}-\mathrm{X}_{\min (\mathrm{y})}}{\mathrm{X}_{\max (\mathrm{y})}-\mathrm{X}_{\min (\mathrm{y})}} \times 100
\end{gathered}
$$

In the equations above, $X_{\min (y)}$ and $X_{\max (y)}$ are the minimum and maximum values of the $y_{j}$ index, respectively; $\mathrm{X}_{(\mathrm{x}, \mathrm{y})}$ is the $\mathrm{y}$ index value of the $\mathrm{X}$ sample; and $X_{p(x, y)}$ and $X_{n(x, y)}$ are the index values of the $x$ sample
Table 5. Determination of $X_{1}$.

\begin{tabular}{|c|c|c|c|c|c|}
\hline Category & I & II & III & IV & V \\
\hline $\mathrm{X}_{1}$ & 1 & 2 & 3 & 4 & 5 \\
\hline
\end{tabular}

with a larger and better value and the index value with a larger and worse value after standardisation, respectively.

\section{Determination of Weights}

SPSS 22.0 software was used for the weight determination. Table 3 shows the weight of each evaluation index of the six evaluation units. The six evaluation units are source, upstream, midstream, downstream, tributary and alpine.

\section{Establishment of the Comprehensive Evaluation Model}

After determining the weights of every single index, a comprehensive evaluation method, linear weighted sum, can be used to quantitatively evaluate the ecosystem health in the Changqing Watershed. This step can be operated by the grid calculator in ArcGIS, and the spatial distribution map can be obtained. The model is simple to implement and can easily compare and further analyse the results. The calculation formula is given by:

$$
\mathrm{I}=\sum_{\mathrm{i}=1}^{\mathrm{n}} \mathrm{W}_{\mathrm{i}} \mathrm{X}_{\mathrm{i}}
$$

...where $\mathrm{W}_{\mathrm{i}}$ is the weight of the $\mathrm{i}$-th evaluation index, $\mathrm{X}_{\mathrm{i}}$ is the normalised value of the $\mathrm{i}$-th indicator and $\mathrm{I}$ is the watershed ecosystem health comprehensive index. The

\begin{tabular}{|c|c|c|}
\hline Grate & Characterisation of state & System characteristics \\
\hline $\begin{array}{c}\mathrm{I} \\
(80-100)\end{array}$ & Excellent & $\begin{array}{l}\text { The ecosystem structure is complete, and the ecosystem service function is perfect. The ecologi- } \\
\text { cal environment is undamaged, and the system has strong ability for recovery and regeneration. }\end{array}$ \\
\hline $\begin{array}{l}\text { II } \\
(60-80)\end{array}$ & Good & $\begin{array}{l}\text { The ecosystem structure is still complete, and the ecosystem service function is relatively } \\
\text { perfect. The ecological environment is less damaged, and the ecosystem can recover under the } \\
\text { interference of general intensity. }\end{array}$ \\
\hline $\begin{array}{c}\text { III } \\
(40-80)\end{array}$ & Fair & $\begin{array}{l}\text { The structure of the ecosystem has changed, but it can still maintain its basic functions. } \\
\text { The ecosystem service functions are degraded, and the ecological environment is damaged to } \\
\text { some extent. After being disturbed by the outside world, the ecosystem has deteriorated and the } \\
\text { ecological problems are serious. }\end{array}$ \\
\hline $\begin{array}{c}\text { IV } \\
(20-40)\end{array}$ & Poor & $\begin{array}{l}\text { The structure of the ecosystem is greatly damaged, its functions are degraded and incomplete, } \\
\text { and the service function of the ecosystem is seriously degraded. The ecological environment is } \\
\text { greatly damaged, and recovery is quite difficult after being disturbed by the outside world. }\end{array}$ \\
\hline $\begin{array}{c}\mathrm{V} \\
(0-20)\end{array}$ & Worse & $\begin{array}{l}\text { The structure of the ecosystem is greatly damaged, and the function of ecological services is } \\
\text { nearly collapsed. The ecological environment is seriously damaged, and its function is lost. } \\
\text { Ecological restoration and reconstruction are very difficult. }\end{array}$ \\
\hline
\end{tabular}
health status of the watershed ecosystem was divided

Table 4. Health status of the ecosystem in the Changqing Watershed. 
into five grades. The specific grade characteristics and significance are shown in Table 4.

\section{Watershed Ecosystem Health Assessment Based on Measured Survey Data}

\section{Evaluation of Water Quality Status}

The single-factor water quality index (WQI) method and the Canadian WQI method were selected to evaluate the water quality of Changqing Watershed [35-42] and to analyse the main pollution factors and the overall water quality of the river watershed. The health status of the ecosystem in the watershed was comprehensive evaluated on the basis of the evaluation results of water quality and habitat quality in the Changqing Watershed [43]. In addition, the average value of the two scores is considered the final comprehensive score.

1. Single-factor WQI method

The single-factor identification index $\mathrm{P}$ is composed of one integer and two decimals and is specifically expressed as follows:

$$
\mathrm{P}=\mathrm{X}_{1} \mathrm{X}_{2} \mathrm{X}_{3}
$$

...where $\mathrm{X}_{1}$ represents the water quality category of the water quality indicator, and $X_{2}$ represents the position of the index to be measured in the water quality category to which it belongs. The larger value indicates that the pollution of the index to be measured in the same water quality category is more serious. In addition, $\mathrm{X}_{3}$ represents the difference between the water quality category of the indicators to be measured and the set category of functional zoning.

The determination of the $X_{1}$ value when the water quality to be evaluated does not exceed class $\mathrm{V}$ water is shown in Table 5.

When the water quality to be evaluated is inferior to class $\mathrm{V}$ water, $\mathrm{X}_{1}$ is expressed as follows:

$$
\mathrm{X}_{1}=\mathrm{N}+5
$$

...where $\mathrm{N}$ evaluates water quality more than $\mathrm{V}$ with overweight multiples of the upper limit value of water; if the bid ratio $\mathrm{N}$ is 3 , then $\mathrm{X}_{1}$ is 8 .

$\mathrm{COD}_{\mathrm{Mn}}, \mathrm{NH}_{3}-\mathrm{N}$ and TP are incremental indicators. Thus, their values increase with the number of water quality categories. Therefore, $\mathrm{X}_{2}$ can be determined by the following formula:

$$
\mathrm{X}_{2}=\frac{\mathrm{C}_{\mathrm{i}}-\mathrm{C}_{\mathrm{ikB}}}{\mathrm{C}_{\mathrm{ikA}}-\mathrm{C}_{\mathrm{ikB}}} \times 10
$$

...where $\mathrm{C}_{\mathrm{i}}$ represents the measured concentration of indicator $i$ and $\mathrm{C}_{\mathrm{ikA}}$ and $\mathrm{C}_{\mathrm{ikB}}$ respectively represent the upper and lower limits of the concentration of the K-th WQI of item $\mathrm{i}$, where $\mathrm{k}$ is $\mathrm{X}_{1}$.
Table 6. Evaluation criteria.

\begin{tabular}{|c|c|}
\hline Water quality category & Numerical range \\
\hline I & $1.0 \leq \mathrm{X}_{1} \mathrm{X}_{2} \leq 2.0$ \\
\hline II & $2.0<\mathrm{X}_{1} \mathrm{X}_{2} \leq 3.0$ \\
\hline III & $3.0<\mathrm{X}_{1} \mathrm{X}_{2} \leq 4.0$ \\
\hline IV & $4.0<\mathrm{X}_{1} \mathrm{X}_{2} \leq 5.0$ \\
\hline V & $5.0<\mathrm{X}_{1} \mathrm{X}_{2} \leq 6.0$ \\
\hline Bad V & $\mathrm{X}_{1} \mathrm{X}_{2}>6.0$ \\
\hline
\end{tabular}

$\mathrm{X}_{3}$ was obtained by comparing the indexes to be evaluated with the categories of water environment functional areas. If the water quality category satisfies or is superior to the category of the functional zone, then $X_{3}=0$. If the water quality category is worse than the functional zone category and $X_{2} \neq 0$, then $\mathrm{X}_{3}=\mathrm{X}_{1}-\mathrm{F}_{\mathrm{i}}$. If the water quality category is worse than the functional area category and $\mathrm{X} 2=0$, then $X_{3}=X_{1}-F_{i}-1$. Fi is the functional area category of the water environment.

The water quality evaluation criteria are shown in Table 6. In accordance with the 'Environmental Quality Standard for Surface Water' (GB 3838-2002), the 'Evaluation Method for Surface Water Quality', temperature (T), $\mathrm{pH}$, electrical conductivity (EC), TDS, chlorophyll a, turbidity, $\mathrm{COD}_{\mathrm{Mn}}, \mathrm{NH}_{3}-\mathrm{N}$ and $\mathrm{TP}$ were selected to evaluate the water quality of the Changqing Watershed. The measured survey indicates that no industrial area exists in the watershed, and the main pollution source is domestic sewage. Therefore, water quality parameters related to agricultural and domestic pollution sources were selected, including $\mathrm{COD}_{\mathrm{Mn}}$, $\mathrm{NH}_{3}-\mathrm{N}$ and TP. These water quality parameters are easy to obtain.

Table 7. Classification of the CCME WQI.

\begin{tabular}{|c|c|c|}
\hline Grade & $\begin{array}{c}\text { Numerical } \\
\text { value }\end{array}$ & meaning \\
\hline Excellent & {$[80,100)$} & $\begin{array}{c}\text { Water quality satisfies all the criteria } \\
\text { for use as a source of drinking water }\end{array}$ \\
\hline Good & {$[60,80)$} & $\begin{array}{c}\text { Water quality rarely or narrowly } \\
\text { iolates the criteria for use as a source } \\
\text { of drinking water }\end{array}$ \\
\hline Fair & {$[40,60)$} & $\begin{array}{c}\text { Water quality often violates the } \\
\text { criteria, possibly by a wide margin, } \\
\text { for use as a source of drinking water }\end{array}$ \\
\hline Poor & {$[20,40)$} & $\begin{array}{c}\text { Water quality often violates the } \\
\text { criteria for use as a source of drink- } \\
\text { ing water by a considerable margin }\end{array}$ \\
\hline Worse & {$[0,20)$} & $\begin{array}{r}\text { Water quality does not satisfy any } \\
\text { criteria for use as a source } \\
\text { of drinking water }\end{array}$ \\
\hline
\end{tabular}


Table 8 . Classification criteria of the stream habitat quality.

\begin{tabular}{|c|c|}
\hline Habitat quality classification & Grading standards \\
\hline Excellent & $\geq 80$ \\
\hline Good & $60 \leq \mathrm{H}<80$ \\
\hline Fair & $40 \leq \mathrm{H}<60$ \\
\hline Poor & $20 \leq \mathrm{H}<40$ \\
\hline Worse & $\leq 20$ \\
\hline
\end{tabular}

\section{CCME WQI}

The Canadian Council of Ministers of the Environment WQI (CCME WQI) is a water quality assessment method constructed by the CCME. It can synthesise the information of the number percentage of indicators exceeding the standard, the number percentage of monitoring values exceeding the standard and the range of monitoring values exceeding the standard. The evaluation results can fully and intuitively reflect the water environment quality of the study area. The CCME WQI can directly provide evaluation results in a percentage system, thus providing a more convenient and faster comprehensive evaluation. CCME WQI is an index defined on (0-100). Its calculation method is given below.

$$
\mathrm{CCME} \text { WQI }=\frac{\sqrt{\mathrm{F}_{1}^{2}+\mathrm{F}_{2}^{2}+\mathrm{F}_{3}^{2}}}{1.732}
$$

In the equation above, $F_{1}$ is the over-standard range, which reflects the percentage of the number of over- standard indicators in the total number of evaluation indicators, and $\mathrm{F}_{2}$ is the over-standard frequency, which reflects the percentage of monitoring times exceeding the total number of monitoring times. In addition, $\mathrm{F}_{3}$ is the over standard range, which represents the average over standard range of the monitoring value. According to the CCME WQI value, the water quality of the water body can be divided into five grades [44], as shown in Table 7.

\section{Habitat Quality Assessment}

Currently, the widely applied river habitat assessment methods include the Rapid Bioassessment Protocols [45-48] recommended by the US Environmental Protection Agency and the Index of Stream Condition (ISC) in Australia [49-50]. A series of representative indicators was selected to evaluate the habitat quality of the watershed based on the specific situation of the study area. The evaluation system includes three categories, namely, rivers channel, riverbank and human disturbance and 10 indexes are available. Each index has a score of 10 points and is scored according to the evaluation criteria. Finally, the scores of each indicator are summed up, and the score is 100 points. Two items are added on the basis of the actual situation in the study area: whether birds and invasive species are observed. When birds are observed, three points are added to the score; when invasive species are found, three points are subtracted from the score. The grading standards of habitat quality are shown in Table 8.

Table 9. Changqing watershed ecosystem health assessment index system.

\begin{tabular}{|c|c|c|}
\hline Target layer & Feature layer & Indicator layer X \\
\hline \multirow{15}{*}{$\begin{array}{l}\text { Health assessment of the water- } \\
\text { shed ecosystem }\end{array}$} & \multirow{6}{*}{ Pressure } & Land reclamation index $\mathrm{X}_{1}$ \\
\hline & & Population density $\mathrm{X}_{2}$ \\
\hline & & Population interference index $\mathrm{X}_{3}$ \\
\hline & & COD emission intensity $\mathrm{X}_{4}$ \\
\hline & & $\mathrm{NH}_{3}-\mathrm{N}$ emission intensity $\mathrm{X}_{5}$ \\
\hline & & Wastewater discharge intensity $\mathrm{X}_{6}$ \\
\hline & \multirow{7}{*}{ Status } & TP load $\mathrm{X}_{7}$ \\
\hline & & Total nitrogen load $\mathrm{X}_{8}$ \\
\hline & & WQI X \\
\hline & & Habitat quality $\mathrm{X}_{10}$ \\
\hline & & Water conservation $\mathrm{X}_{11}$ \\
\hline & & Ecological elasticity $\mathrm{X}_{12}$ \\
\hline & & Connectivity index $\mathrm{X}_{13}$ \\
\hline & \multirow{2}{*}{ Response } & Soil erosion sensitivity index $\mathrm{X}_{14}$ \\
\hline & & Environmental governance input index $\mathrm{X}_{15}$ \\
\hline
\end{tabular}


Table 10. Indicator weights of the ecosystem health evaluation in the Changqing Watershed.

\begin{tabular}{|c|c|c|}
\hline $\begin{array}{c}\text { Indicator } \\
\text { code } \mathrm{X}_{\mathrm{i}}\end{array}$ & Indicator name & $\begin{array}{c}\text { Weights } \\
\mathrm{W}_{\mathrm{i}}\end{array}$ \\
\hline $\mathrm{X}_{1}$ & Population density & 0.0351 \\
\hline $\mathrm{X}_{2}$ & Land reclamation index & 0.0575 \\
\hline $\mathrm{X}_{3}$ & Human disturbance index & 0.0769 \\
\hline $\mathrm{X}_{4}$ & COD emissions intensity & 0.0449 \\
\hline $\mathrm{X}_{5}$ & $\mathrm{NH}_{3}$-N emission intensity & 0.0868 \\
\hline $\mathrm{X}_{6}$ & Wastewater discharge intensity & 0.0501 \\
\hline $\mathrm{X}_{7}$ & TP load & 0.0844 \\
\hline $\mathrm{X}_{8}$ & Total nitrogen load & 0.0845 \\
\hline $\mathrm{X}_{9}$ & Habitat quality & 0.0755 \\
\hline $\mathrm{X}_{10}$ & Connectivity index & 0.0295 \\
\hline $\mathrm{X}_{11}$ & WQI & 0.0795 \\
\hline $\mathrm{X}_{12}$ & Water conservation index & 0.0803 \\
\hline $\mathrm{X}_{13}$ & Ecological elasticity & 0.0775 \\
\hline $\mathrm{X}_{14}$ & Soil erosion sensitivity index & 0.0808 \\
\hline $\mathrm{X}_{15}$ & Environmental governance input index & 0.0567 \\
\hline
\end{tabular}

\section{Watershed Ecosystem Health Assessment Based on Multi-Source Data}

This method is an evaluation index system constructed by integrating remote sensing data and measured survey data. Referring to the P-S-R model [51-53], the appropriate indicators were selected from the three levels of pressure, state and response, and an evaluation index system was constructed to evaluate the ecosystem health in the study area, as shown in Table 9. The selection principle, evaluation criteria, standardisation processing of evaluation indicators and weight determination methods of the evaluation indicators are all consistent with the previous studies to facilitate comparison with previous evaluation results. The definition of each index is listed in Appendix B.

\section{Determination of the Indicator Weights}

The weights of each indicator were determined according to the principal component analysis method, and the weight values of each indicator are shown in Table 10.

\section{Results and Discussion}

\section{Comprehensive Evaluation of Watershed Ecosystem Health Based on Remote Sensing Data}

Using the weight value obtained through calculation and analysis, the spatial distribution map of the health

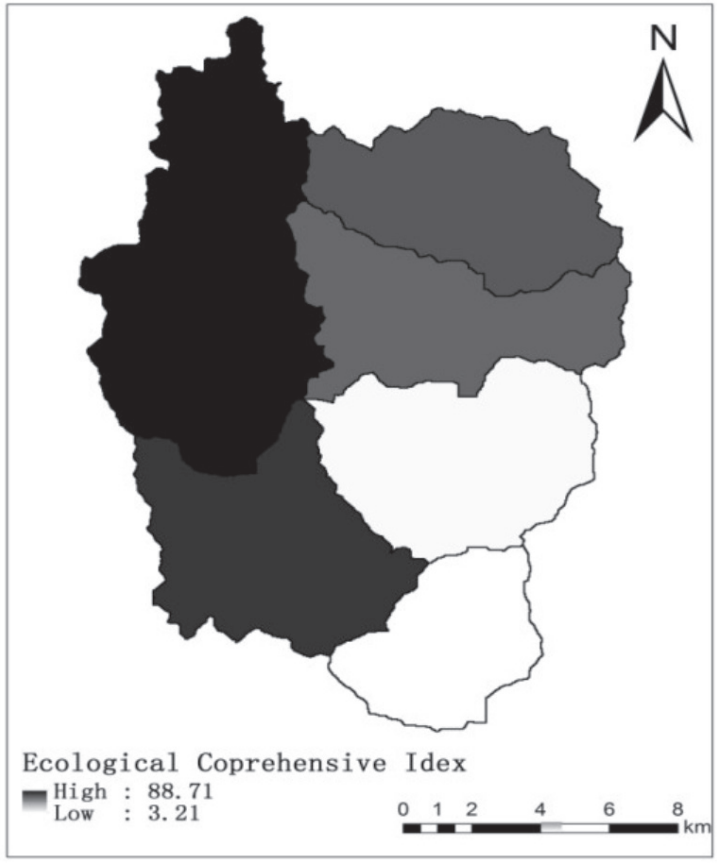

Fig. 4. Spatial distribution map of river watershed ecosystem health status.

status of the watershed ecosystem is obtained through the weighted summation module in ArcGIS 10.2 software, as shown in Fig. 4.

Fig. 4 and Table 11 show that the evaluation results are obtained by considering six evaluation units. The final comprehensive score obtained from the remote sensing data is 71.03 , which indicates that the overall health status of the ecosystem in Changqing Watershed is acceptable. The area proportion of the first- and second-level ecosystem health status in the Changqing Watershed exceeded $70 \%$, and the area proportion of the region with poor ecosystem health status is $9.92 \%$. This finding indicates that the overall ecosystem status of the watershed is acceptable. The area proportion of ecosystem health status in the study area is excellent, good, fair and poor from high to low. The first-grade 'excellent' area is the largest at $111.28 \mathrm{~km}^{2}$. The secondary area is $75.19 \mathrm{~km}^{2}$, and the area proportion of the two areas is nearly $74 \%$. The fifth-level 'worse' area

Table 11. Results of the ecosystem health assessment of the Changqing Watershed.

\begin{tabular}{|c|c|c|}
\hline Level & Area $\mathrm{km}^{2}$ & Percentage $\%$ \\
\hline Fifth levels (0-20) & 25.13 & 9.92 \\
\hline Fourth levels (20-40) & 0 & 0 \\
\hline Third levels (40-60) & 41.54 & 16.41 \\
\hline Second class (60-80) & 75.19 & 29.71 \\
\hline First level (80-100) & 111.28 & 43.96 \\
\hline Comprehensive score & \multicolumn{2}{|c|}{70.29} \\
\hline
\end{tabular}


is relatively small at $25.13 \mathrm{~km}^{2}$, with an area ratio of $9.92 \%$.

\section{Evaluation and Analysis Based on Measured Data}

The monitoring data of $\mathrm{COD}_{\mathrm{Mn}}, \mathrm{NH}_{3}-\mathrm{N}, \mathrm{TP}$ and other indicators were selected to evaluate the water quality of the Changqing Watershed by single-factor WQI identification method and the Canadian WQI method. The corresponding evaluation results are shown in Table 12. In accordance with the actual situation of the watershed, 10 evaluation indexes were selected to evaluate the habitat quality of the watershed. The evaluation results are shown in Table 13

According to the evaluation results of the CCME WQI, the overall water quality of the Changqing Watershed is in good condition, but the comprehensive score of S2, S4 and S5 is relatively low. Combined with the single-factor WQI identification method, the finding shows that the WQIs monitored only exceeds the limited standards at some points in the midstream and downstream, and the degree of exceeding the standard is only low. The specific cases that exceed the standard are as follows: COD index values of S2 and S5 points exceed the standard with the single-factor identification indexes of 4.11 and 4.41, respectively. These results indicate that the current water body is inferior to the target water body in the functional area and the exceeding rates are $11 \%$ and $42 \%$, respectively. The TP index value at the S5 point exceeds the standard, and the single-factor identification index is 4.21, indicating that the current water body is inferior to the target water body in the functional area and the exceeding rate is $11 \%$.

The habitat quality evaluation results show that the overall habitat quality of the Changqing Watershed is mainly in a fair-good state, and some sites are greatly disturbed and destroyed. The habitat quality of more than half of the surveyed sites in the study area is good, accounting for $66.6 \%$. The habitat quality of the remaining sites, accounting for $33.3 \%$, is fair. The samples in the study area indicate that the overall habitat quality of Sanfeng village, Xiaji village and the viaduct is better. The scores of various index values indicate that the scores of substrate, habitat complexity, embankment stability, water volume, vegetation diversity and sanitation of the shore are generally high. Thus, these habitat conditions are ideal in most river sections of the watershed, and the degree of damage and impact is relatively low. The two universal scores of land-use type and human activity intensity on both sides of the river bank are relatively low. These results indicate that the river watershed is also strongly affected by human activities, such as the nonpoint source pollution of damming at the riverbank, establishment of hydropower station, living source and agricultural source. These indicators are the key aspects of the restoration and improvement of the habitat of the Changqing Watershed in the later stage.

On the basis of the evaluation results of the water quality and habitat quality of the Changqing Watershed, the ecosystem health status of the Changqing Watershed is comprehensively evaluated. The average value of the two scores is 77.68 , which is considered the final comprehensive score. Therefore, the ecosystem health of the Changqing Watershed is generally good. The result also indicates that the Alpine area and Tributary area are the best, the ecological conditions of the source and upstream are healthier than those of the midstream and downstream, and the health condition of the midstream is poor. The reason may be that the midstream is located in the centre of Changqing town, where villagers gather and the population density is large. In addition, the pollution discharge activities of enterprises and farms in the area further damage the ecology of the watershed.

Table 12. Water quality evaluation results.

\begin{tabular}{|c|c|c|c|c|c|c|}
\hline \multirow{2}{*}{ Monitoring section } & \multirow{2}{*}{$\begin{array}{c}\text { Location } \\
\text { description }\end{array}$} & \multirow{2}{*}{$\begin{array}{c}\text { Water environment } \\
\text { functional zone target }\end{array}$} & \multicolumn{3}{|c|}{ Single-factor WQI method } & \multirow{2}{*}{$\begin{array}{c}\text { CCME } \\
\text { WQI }\end{array}$} \\
\cline { 5 - 7 } & Luyang Bridge & III & 3.70 & 2.70 & 1.20 & 100 \\
\hline S1 & Sanfeng Village & III & 4.11 & 1.60 & 1.10 & 72.8 \\
\hline S2 & Xiayu Village & III & 1.60 & 1.50 & 1.30 & 100 \\
\hline S3 S4 & Changqing Middle & III & 2.20 & 1.50 & 4.21 & 76.8 \\
\hline S5 & Changqing Township & III & 4.41 & 1.70 & 1.50 & 72.8 \\
\hline S6 & Viaduct & III & 1.50 & 1.30 & 1.10 & 100 \\
\hline S7 & Zhongpu Village & III & 1.60 & 1.20 & 1.30 & 100 \\
\hline S8 & Zekou & III & 3.80 & 1.50 & 1.50 & 100 \\
\hline S9 & Lianfeng Village & III & 1.40 & 1.60 & 1.80 & 100 \\
\hline
\end{tabular}




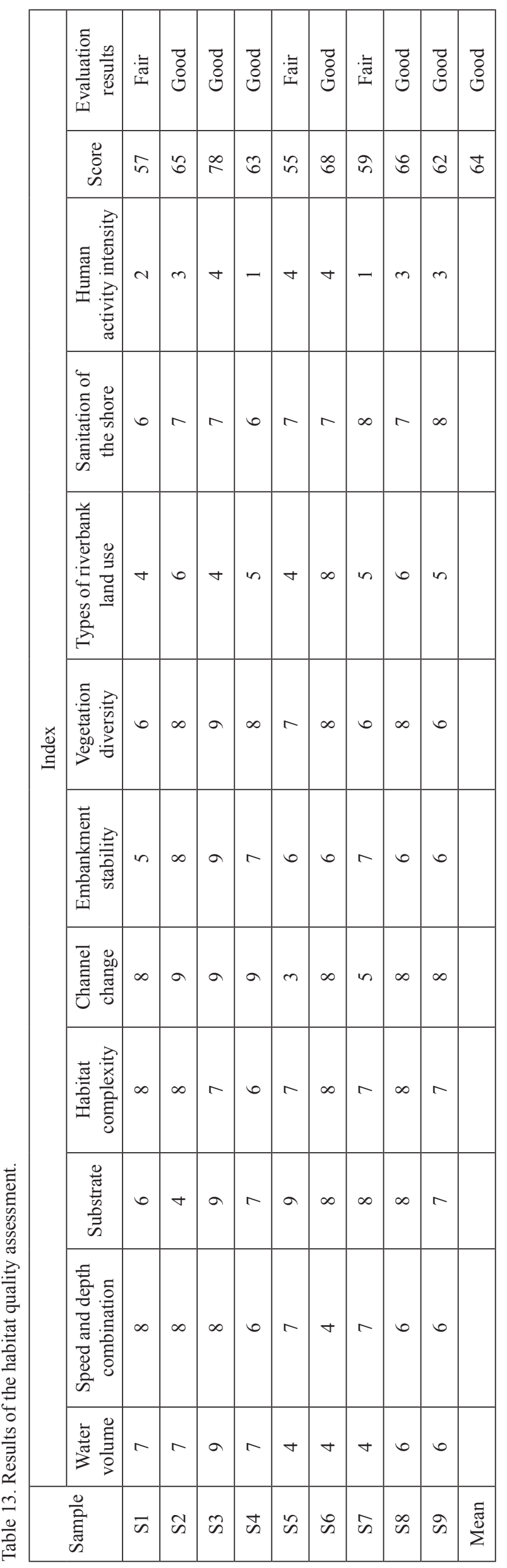

Comprehensive Evaluation of Watershed Ecosystem Health Based on Multi-Source Data

Through the grid calculator in ArcGIS, the statistical calculation of the area of each grade was done. The results are shown in Table 14.

Fig. 5 and Table 14 show that the health status of the Changqing Watershed ecosystem is excellent-good, and the proportion of the area is more than $70 \%$. No area has an ecosystem with poor health status ecosystem, and the overall ecological condition is good. The area ratios of the ecosystem health status in the study area are excellent, good and poor. Among them, the excellent and good ecological environments account for large areas with sizes of $111.28 \mathrm{~km}^{2}$ and $75.19 \mathrm{~km}^{2}$, respectively, and the total area ratio is nearly $74 \%$. The area with poor ecosystem health is relatively small, accounting for $66.66 \mathrm{~km}^{2}$ and $26.33 \%$ of the total area. The health status of the ecosystems in Alpine area and Tributary area is evidently better than that in the mainstream area, where residents gather, especially

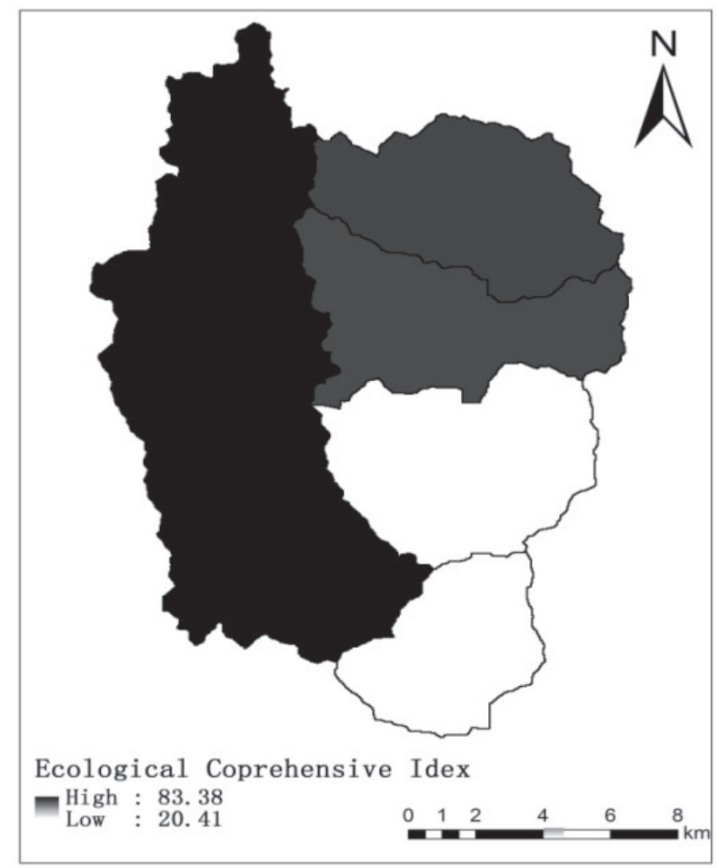

Fig. 5. Comprehensive Evaluation Value.

Table 14. Area and proportion of each level.

\begin{tabular}{|c|c|c|}
\hline Level & Area $\mathrm{km}^{2}$ & Percentage $\%$ \\
\hline Fifth levels (0-20) & 0 & 0 \\
\hline Fourth levels (20-40) & 66.66 & 26.33 \\
\hline Third levels (40-60) & 0 & 0 \\
\hline Second class (60-80) & 75.19 & 29.71 \\
\hline First level (80-100) & 111.28 & 43.96 \\
\hline Comprehensive score & \multicolumn{2}{|c|}{63.87} \\
\hline
\end{tabular}



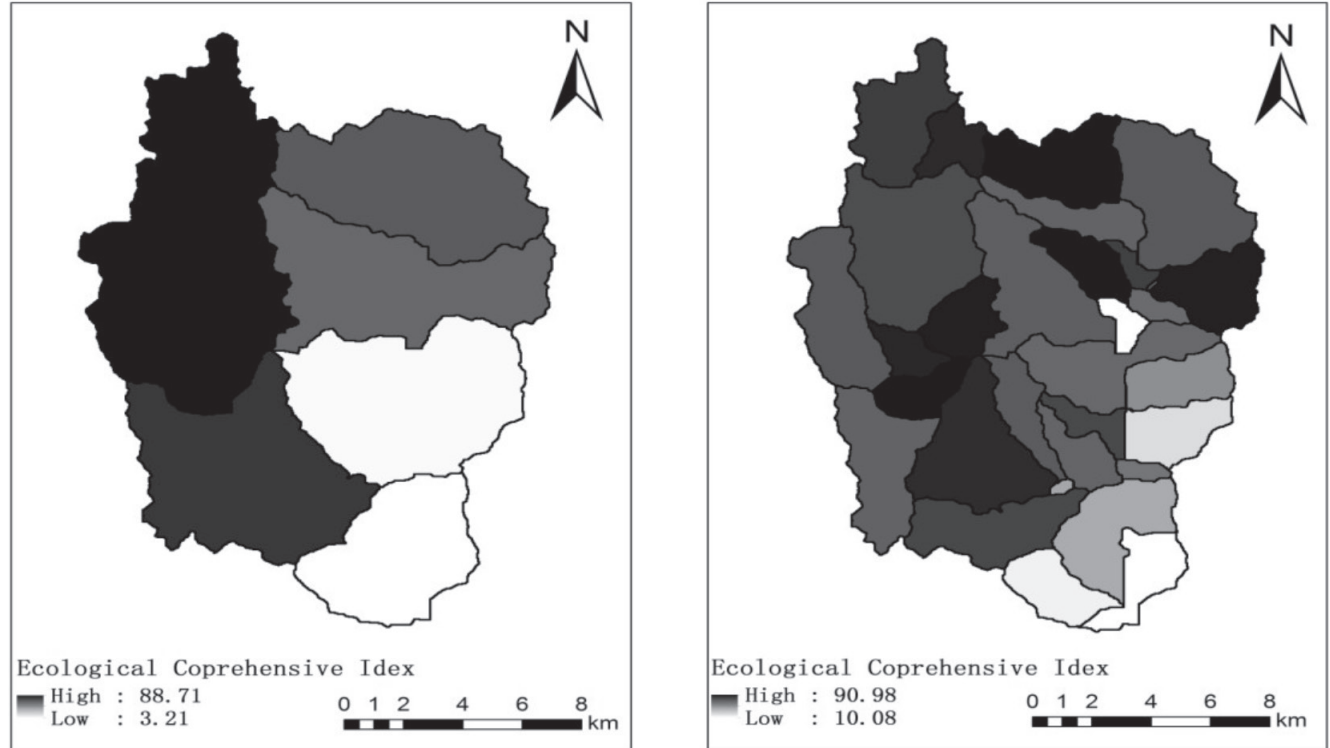

Fig. 6. Spatial distribution map of watershed ecosystem health status.

in the midstream and downstream. The midstream and downstream of the ecosystem has poor health because of the non-natural land use that accounts for a large proportion of the area, the pollution discharge activities of enterprises and the high intensity of human interference.

\section{Comprehensive Evaluation and Analysis of Each Evaluation Method}

\section{Evaluation and Analysis Based on Remote Sensing Data}

Based on the remote sensing data and the actual situation of the research area, this paper selects the corresponding evaluation indicators and constructs a suitable evaluation index system to comprehensively evaluate the ecological health of Changqing Watershed. There are two basic units for evaluation: the subwatershed divided by BASINS software is the basic unit for evaluation and the six areas determined by terrain characteristics combined with administrative divisions are the basic units for evaluation. The scale problem has been a hot topic in the field of remote sensing, and the research on the impact of different evaluation scales on the evaluation results has continued.

Combined with Fig. 6 and Table 15, it can be seen that the evaluation results based on the six areas are as follows: the proportion of the area with "excellentgood" level of the ecosystem health status in the Changqing Watershed is over $70 \%$. The proportion of the area with "poor" level of the ecosystem health status is $9.92 \%$, and the overall ecological status of the basin is good. The area ratio of ecosystem health status in the study area is excellent, good, general and poor, respectively. Among them, excellent and good ecological environment quality accounts for a large area of $111.28 \mathrm{~km}^{2}$ and $75.19 \mathrm{~km}^{2}$, respectively, accounting for nearly $74 \%$ of the total area. The area with poor ecosystem health is relatively small, accounting for $25.13 \mathrm{~km}^{2}$ and $9.92 \%$ of the total area.

Table 15. Results of the ecosystem health assessment of Changqing Watershed.

\begin{tabular}{|c|c|c|c|c|}
\hline \multirow{3}{*}{ Level } & \multicolumn{4}{|c|}{ Evaluation unit } \\
\hline & \multicolumn{2}{|c|}{6 Units } & \multicolumn{2}{|c|}{31 Sub-basins } \\
\hline & Area $\mathrm{km}^{2}$ & Percentage $\%$ & Area km² & Percentage $\%$ \\
\hline Five-levels (0-20) & 25.13 & 9.92 & 15.43 & 6.09 \\
\hline Four-level (20-40) & 0 & 0 & 7.27 & 2.87 \\
\hline Three-level (40-60) & 41.54 & 16.41 & 19.26 & 7.61 \\
\hline Second-class (60-80) & 75.19 & 29.71 & 134.50 & 53.13 \\
\hline First level (80-100) & 111.28 & 43.96 & 76.71 & 30.31 \\
\hline Comprehensive score & \multicolumn{2}{|c|}{70.29} & \multicolumn{2}{|c|}{71.03} \\
\hline
\end{tabular}


The evaluation results based on the 31 subwatershed as the evaluation unit. The area proportion of the Changqing Watershed ecosystem health status of "excellent-good" was more than $83 \%$. The area proportion of the region with poor ecosystem health status was $6.09 \%$, and the overall ecological status of the basin was good. The area ratio of ecosystem health status in the study area is excellent, good, general and poor, respectively. Among them,excellent and good ecological environment quality accounts for a large area of $76.71 \mathrm{~km}^{2}$ and $134.5 \mathrm{~km}^{2}$ respectively, and the area ratio is nearly $84 \%$ in total. The area with poor ecosystem health is relatively small, accounting for $15.43 \mathrm{~km}^{2}$ and $6.09 \%$ of the total area.

There is a difference between the two evaluation results in the proportion of area occupied by each grade, the proportion of area occupied by the two in the above three grades is only $0.96 \%$, and the final overall comprehensive score is only 0.74 , which can be regarded as equivalent. However, more basic evaluation units can show more obvious spatial differences. On the premise of data availability, more basic evaluation units should be properly divided. In this study, although the scale of the basic evaluation unit sub-watershed is smaller than that of the area. Due to the small scope of the study area itself, the scale effect in the study is also very small. In the assessment of the health of a small watershed ecosystem, due to its small watershed range, changes in climate and meteorology are basically negligible, and it is regarded as the same meteorological and climatic conditions. The changes of topographic features are not too complicated, so there is no need to consider too much the impact of the evaluation scale on the evaluation results, but should pay attention to whether the required evaluation index data can be obtained.

The advantage of using remote sensing data to evaluate the health status of the watershed ecosystem is that they can directly reflect the distribution of the regional ecosystem health status in space. The classification of the land-use types by remote sensing can satisfy the requirements of evaluation. However, in remote sensing evaluation, the impact of the same land-use type on the regional ecological environment is the same. Although the overall analysis and evaluation can be carried out from the level of different land types, identifying individual pollution sources with consideration to local special conditions is difficult. Therefore, when pollution sources, such as industrial enterprises or livestock and poultry breeding, exist in the evaluation area, the evaluation based on remote sensing data obtains the preferred results.

\section{Evaluation and Analysis Based on Measured Data}

The advantage of field investigation and monitoring is that it can clearly understand the situation inside and on both sides of the river, including the water volume, garbage and pollution discharge in the river. It also focuses on the pollution of point sources, which is an indispensable link for the subsequent environmental governance and ecological restoration of the river watershed. The local residents understand the surrounding conditions of their residence, including the locations of industrial enterprises, large-scale livestock and poultry breeding and the water quality of the river, because the small area of the small watershed is conducive to field investigation and monitoring. Thus, the difficulty of field investigation is reduced.

However, the problem is that the process involving sample collection, transportation or data analysis is time consuming and laborious. In addition, we should focus on the preservation of samples. The three aspects that are used to evaluate the ecosystem health status in the watershed include water quality, habitat quality and biological integrity. The biological integrity index method is inapplicable to the ecosystem health assessment of small watershed. Obtaining sufficient samples for assessment is difficult because the
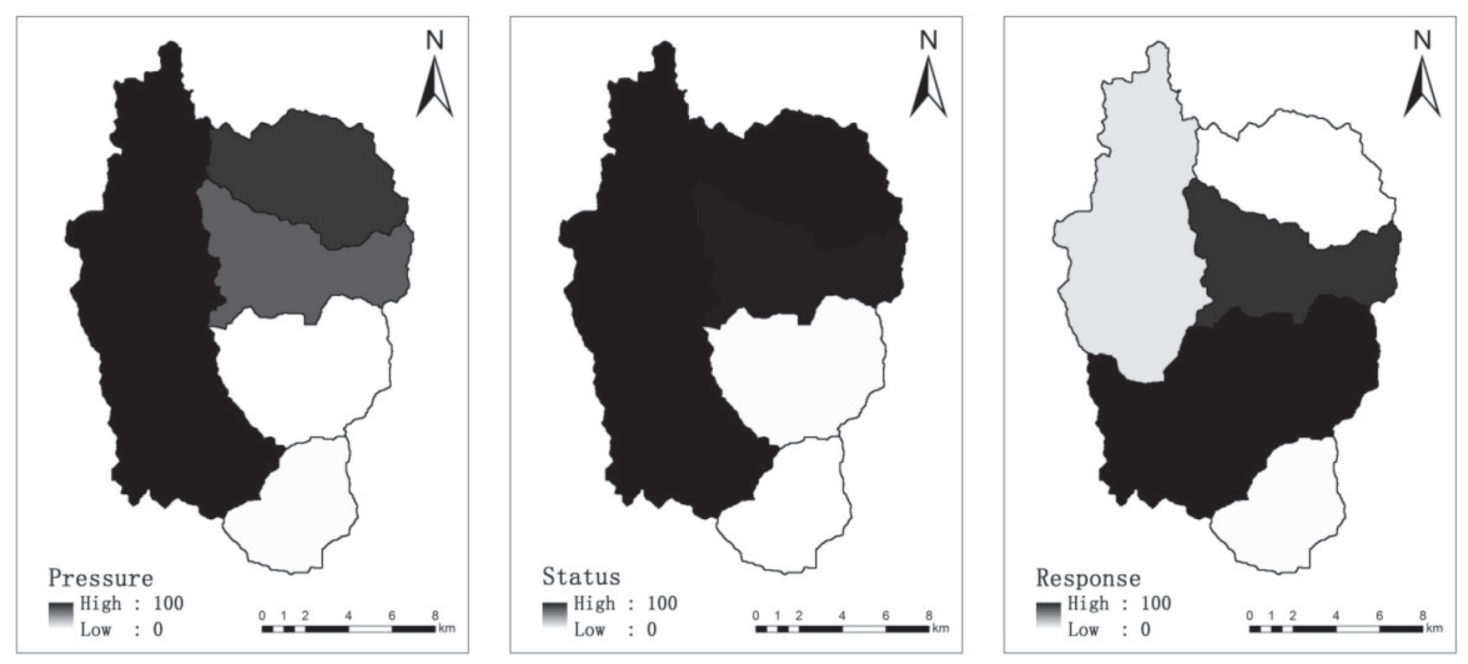

Fig. 7. Distribution of pressure, status, and response indicators. 
biological resources of the small watershed are limited. In addition, a large collection of biological samples also damages the ecology of the small watershed, which is also contrary to the original intention of this study. Therefore, the method of biological integrity is unsuitable for the assessment of ecosystem health in a small watershed.

\section{Evaluation and Analysis Based on Multi-Source Data}

It can be seen from the comprehensive evaluation distribution map of the pressure index (Fig. 7) that the high mountainous area, the tributary area and the source area are under less pressure, and the pressure in the middle and lower reaches is relatively large. Through the calculation of relevant modules in ArcGIS, it is concluded that the pressure index belongs to the first-level "excellent" zone, with an area of $149.38 \mathrm{~km}^{2}$, accounting for $59 \%$. The area of the second-class "good" zone is $37.12 \mathrm{~km}^{2}$, accounting for $37.12 \mathrm{~km}^{2}$. The pressure in the middle and lower reaches is relatively large. The reason is that the region is a township of Changqing town, where residents gather, the population density is large, the proportion of cultivated land and construction land is also large, and the industrial enterprises discharge pollution, which has a great impact on the natural ecosystem.

It can be seen from the distribution map of comprehensive evaluation of state index that the distribution map of comprehensive evaluation results of state indicators in the study area is similar to the distribution map of comprehensive evaluation of pressure index to a certain extent, which is better in mountains, tributaries and source areas, and relatively poor in the middle and lower reaches. According to the statistical calculation, the state index is the largest in the first level "excellent" area, with an area of $186.5 \mathrm{~km}^{2}$, accounting for $73.67 \%$. The second and third level areas are missing. The fourth level "poor" area is $41.53 \mathrm{~km}^{2}$, accounting for $16.41 \%$. The area of grade five "poor" area is $25.13 \mathrm{~km}^{2}$, accounting for $9.93 \%$. In the areas with better health status, vegetation coverage is higher, water conservation capacity is stronger, soil conservation capacity is weaker, and human interference is stronger, while in the areas with worse health status, the situation is the opposite.

It can be seen from the distribution map of comprehensive evaluation results of response index that the ecosystem health response of Changqing Watershed is in a general state. Among them, the first-level "excellent" area is missing. The area of the second-level "good" area is $41.53 \mathrm{~km}^{2}$, accounting for $16.41 \%$. The area of the third-level "general" area is $79.35 \mathrm{~km}^{2}$, accounting for $31.34 \%$. The area of the fourth-level "poor" area is $94.20 \mathrm{~km}^{2}$, accounting for $37.21 \%$. The area of the fifth-level "poor" area is $38.08 \mathrm{~km}^{2}$, accounting for $15.04 \%$. The response index of the middle reaches is the best, because it is the town center and the investment of governance is relatively large. On the whole, the distribution of response index grade is opposite to that of state and pressure index grade.

\section{Analysis of the Difference between Multi-Source and Remote Sensing Evaluation Methods}

The advantages of multi-source data are evident given that many types of indicators and a large amount of information are available, which can be used to obtain a more reasonable and accurate assessment of the regional ecosystem health. However, the problem of multi-source data evaluation lies in the data availability. Not all areas to be evaluated can produce sufficient data and some evaluation index data may be unavailable, especially in small watersheds at the township level. The comparative results of the ecosystem health assessment based on remote sensing data indicate that
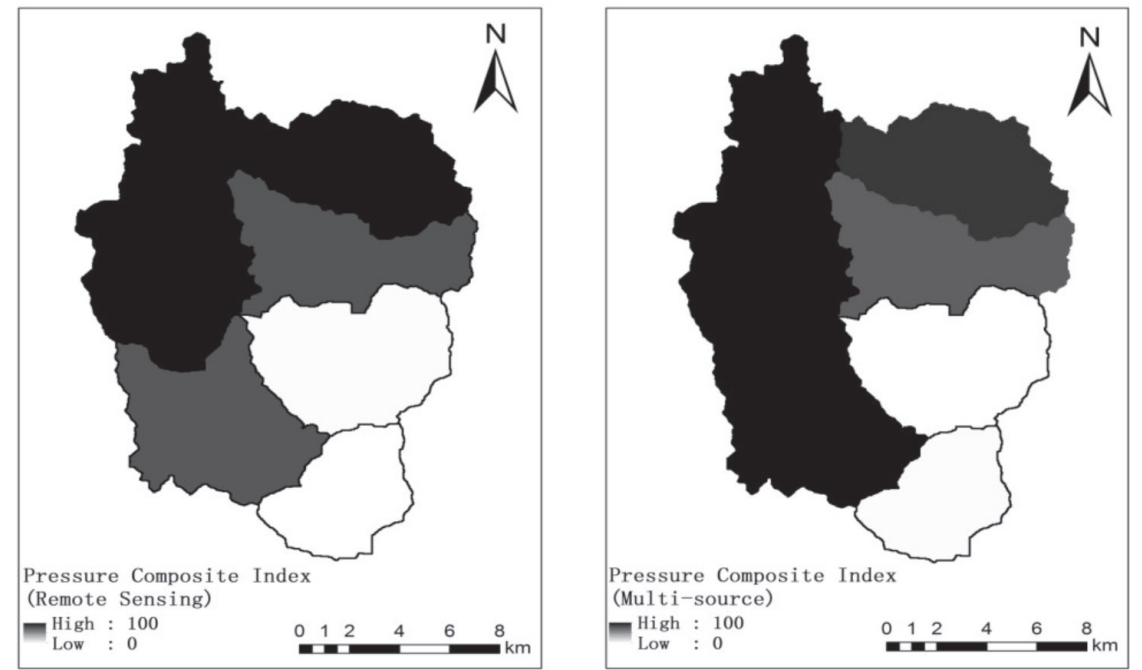

Fig. 8. Comparison of pressure comprehensive evaluation value. 


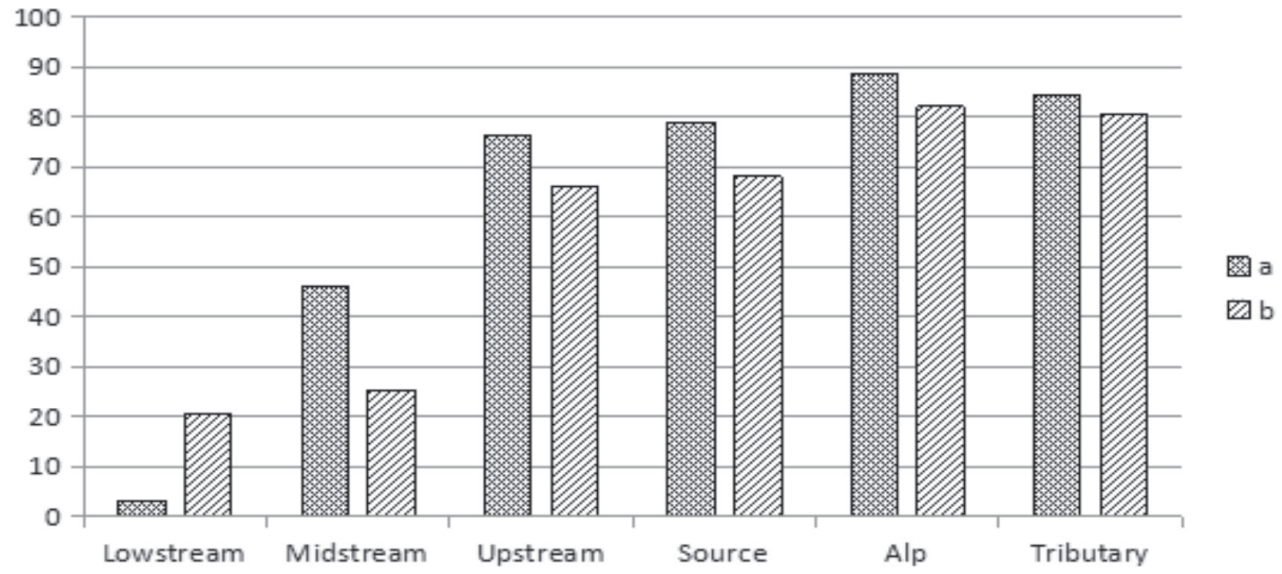

Fig. 9. Comprehensive evaluation value of each evaluation unit (a represents based on remote sensing data and $b$ represents based on multi-source data).

the results obtained using remote sensing data are better than those obtained using multi-source data.

Fig. 7 shows that except in the downstream area, the evaluation results based on remote sensing data are better than those based on multi-source data. The reason is that the simple remote sensing data analysis is mainly focused on land-use types, and the natural land accounts for a large proportion. Thus, the health of its ecosystem is better; otherwise, its health is worse. The analysis based on multi-source data adds some pressure indicators to the evaluation index system, resulting in low scores for each region (Fig. 8). In this aspect, the performance in the midstream becomes more evident because enterprise sewage activities exist in the midstream. This condition cannot be considered by remote sensing data. Figs 6 and 7 show that the change in evaluation results in the midstream is larger than that in the upstream, source, alpine and tributary, and the comprehensive score is reduced from 46.12 to 25.32 . Moreover, the 'abnormal value' in the downstream is caused by the evaluation mechanism of remote sensing data. The remote sensing evaluation index with the land-use type as the core is assigned to the lowest value in the downstream area, because the proportion of unnatural land in the downstream area is large. As a result, in the process of index value standardisation, the index value in the downstream often falls to the lowest value region. In the evaluation system based on multisource data, more indicators are available. In addition, the lowest value of more evaluation indicators does not appear in the downstream area but in other areas, thus improving the comprehensive score of the downstream area. More comprehensive evaluation and analysis can be conducted because the multi-source data evaluation method adds more pollution evaluation indicators.

\section{Analysis of the Differences Among the Three Evaluation Methods}

Fig. 9 shows that the three evaluation results are within the range of 60-80 of the same grade; the highest score is based on measured data, and the lowest score is based on multi-source data. The previous analysis reveals that the evaluation based on multi-source data is the most reasonable and accurate. The evaluation results based on remote sensing data or measured data are extremely high due to the insufficient evaluation indicators that can reflect the ecological health of the

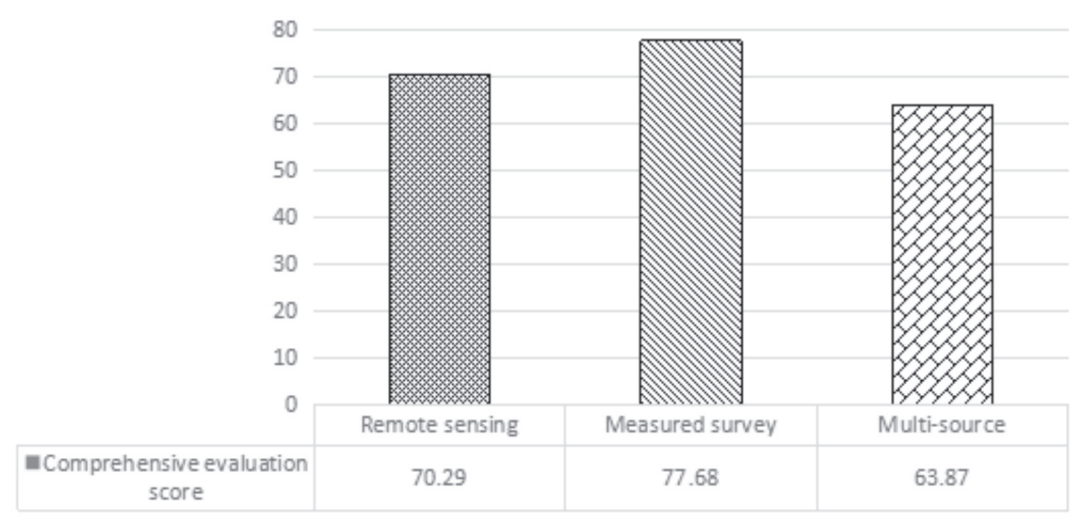

Fig. 10. Comprehensive evaluation value of watershed ecosystem. 
watershed. Obtaining the data in the study area is difficult. This important factor restricts the ecosystem health assessment of small watershed.

When pollution sources, such as industrial enterprise pollution or livestock and poultry breeding, exist in the evaluation area, remote sensing data cannot consider these special pollution sources. However, the small watershed area is small, and the local area has relatively great impact in general. These findings indicate that the evaluation results based on remote sensing data are better than those obtained from using multi-source data. Although the evaluation method based on remote sensing data can overcome the problem of missing data, it still needs some other data to assist especially in the distribution of industrial enterprises and pollution discharge in the region. Sampling points should be set reasonably for investigation and monitoring to obtain relatively accurate evaluation results.

Field investigation and monitoring can only cover local areas, and the entire content cannot be acquired. Multiple local areas can reflect the overall state, which inevitably leaves out part of the information. Thus, the results are better than the evaluation results obtained by the other two methods. The evaluation method based on the measured data is relatively suitable, considering only the function of the water environment in the watershed. Through the measured data, we can determine the emission intensity of pollution and the pollution load of the region as well as formulate the corresponding treatment measures and schemes. However, the layout of the sampling points, sampling time and frequency and its rationality directly affect the evaluation results.

Studies on small watershed at home and abroad are few due to the difficulty of obtaining data on small watersheds. The present study provides new ideas and methods for the research of small watershed ecosystem health through three evaluation methods. The appropriate method to build the evaluation system should be determined based on the availability of data in the study area. When the study area can only generate a small amount of data that are difficult to obtain, the use of remote sensing data methods will inevitably cause great uncertainty. Although the evaluation method of remote sensing data is the simplest, it is highly dependent on data and needs a considerable amount of other data for support. Meanwhile, obtaining data from the measure survey and evaluation method is difficult as it can only consider localities and cannot reflect the overall situation of the study area. In relation to this, the remote sensing and measure survey evaluation methods can be used for initial evaluation. Therefore, according to the different scenarios of this study, the basic idea of comprehensive assessment of ecosystem health in small watersheds is introduced.

1. Sufficient data are available in the study area

We need to pay attention to whether pollution sources, such as industrial enterprises pollution and livestock breeding, exist in the watershed. If no pollution sources are available, then we can directly use remote sensing data and basic social and economic data for evaluation. If pollution exists, then evaluating the emission intensity of pollution in the evaluation area is necessary.

2. Lack of information and data in the study area

In order to scientifically assess the ecosystem health of small watershed without adequate information and data, firstly we can obtain the field data such as habitat quality status, discharge wastewater from industrial enterprises, physical and chemical indicators of water body in different cross sections of river. Secondly, combined with the data obtained by remote sensing, such as soil erosion and land reclamation index, a reasonable evaluation system is constructed to scientifically evaluate the health of small watershed ecosystems. Thirdly, biological investigation data can improve the evaluation system of small watershed, for example, fish species and quantity information in the watershed can greatly benefit the integrity of evaluation system. Field investigation and monitoring are necessary to obtain sufficient data and evaluate the research area with remote sensing data. In addition, under the condition of ensuring the availability of data, more detailed evaluation units should be divided. The evaluation results will have better comparability in spatial distribution and better support for the followup environmental protection governance and ecological restoration.

\section{Conclusions}

The main conclusions of this paper can be summarised as follows.

(1)The results based on remote sensing data show that the overall condition is good. The sum of the area ratios of the first-level (excellent) and secondlevel (good) areas can reach $70 \%$, and the proportion of areas with poor ecosystem health is below $10 \%$. The evaluation results of the field survey indicate that the overall ecological health of the river basin is good. The tributary and source have the best ecological health, and the middle and lower reaches are the worst. The evaluation results based on multi-source data show that the proportion of the area with the grade of excellentgood is nearly $74 \%$, and the overall ecological health of the river basin is good. The multi-source data were used by the combination of remote sensing data and measure survey data, and the final score was the lowest. High accuracy is also achieved using remote sensing data and field survey evaluation methods.

(2)The results from remote sensing data to evaluate the health of watershed ecosystem are better than those based on multi-source data. The lack of evaluation system composed of simple remote sensing data causes the evaluation of local individual pollution to become inaccurate, and because of the small research area, the local areas have a relatively large impact in general. Therefore, in assessing the health of small watershed 
ecosystems, the method based on remote sensing data is suitable for the initial assessment. Only when the data in the study area is sufficient and no special pollution source exists (such as industrial pollution source) can the evaluation method based on remote sensing data be used directly. When the study area lacks data, combining measure survey to obtain data is necessary, especially the distribution of industrial enterprises and pollution discharge in the area. Moreover, sampling points should be reasonably set for investigation and monitoring in order to obtain relatively accurate evaluation results.

\section{Appendix}

A. Accuracy evaluation of land cover classification.

\begin{tabular}{|c|c|c|c|}
\hline Land use types & User accuracy \% & Total accuracy $\%$ & Kappa Coefficient \\
\hline Bare land & 94.74 & \multirow{6}{*}{93.33} & \multirow{6}{*}{0.9011} \\
\hline Wood land & 88.49 & & \\
\hline Arable land & 85.71 & & \\
\hline Construction land & 83.33 & & \\
\hline Slash & 89.47 & & \\
\hline Water body & 98.06 & & \\
\hline
\end{tabular}

B. Calculation process of each evaluation index based on remote sensing and multi-source evaluation.

\begin{tabular}{|c|c|}
\hline $\begin{array}{l}\text { Evaluation } \\
\text { index }\end{array}$ & Index Interpretation and calculation process \\
\hline $\begin{array}{l}\text { Land reclama- } \\
\text { tion index }\end{array}$ & $\begin{array}{l}\text { Land reclamation index refers to the proportion of the area of cultivated land in the total area of a region, which } \\
\text { indicates the sustainable utilisation of land for human beings. The land use classification map was obtained by } \\
\text { interpreting the remote sensing images of the study area. The area of cultivated land in the area was extracted using } \\
\text { ArcGIS } 10.2 \text { software and calculated according to Formula (1-1). After data standardisation, the land reclamation } \\
\text { index distribution map was drawn. } \\
\qquad \mathrm{K}=\frac{\mathrm{S}_{\mathrm{g}}}{\mathrm{S}_{\mathrm{z}}} \\
\qquad \mathrm{S}_{\mathrm{g}} \text { : cultivated land area. } \mathrm{S}_{\mathrm{z}} \text { : evaluation area. K: land reclamation index. }\end{array}$ \\
\hline $\begin{array}{l}\text { Population } \\
\text { interference } \\
\text { index }\end{array}$ & $\begin{array}{l}\text { Population interference index refers to the proportion of the area of regional construction land to the total area of } \\
\text { the region, which indicates the degree of human interference on regional ecology. ArcGIS software was used to } \\
\text { extract the construction map layer of this area, which was then calculated according to Formula (1-2). After the } \\
\text { standardisation of data, the distribution map of population interference degree index was finally drawn. } \\
\qquad \mathrm{P}=\frac{\mathrm{S}_{\mathrm{j}}}{\mathrm{S}_{\mathrm{z}}} \\
\text { P: population interference index. } \mathrm{S}_{\mathrm{z}} \text { : area of evaluation area. } \mathrm{S}_{\mathrm{j}} \text { : construction land area }\end{array}$ \\
\hline TP/TN load & $\begin{array}{l}\text { Total phosphorus and total nitrogen load refer to the total amounts of total phosphorus and total nitrogen per } \\
\text { square kilometre of land in the evaluation area, respectively, thus indicating the pressure on the watershed ecology. } \\
\text { The pollutant loading (PLOAD) model in the watershed system was used to calculate the annual pollution load of } \\
\text { TP and total nitrogen in the watershed. The GIS data and tabular data required to run the PLOAD model include } \\
\text { boundary layer of Changqing watersheds, land cover type map of Changqing Watershed, EMC value and impervi- } \\
\text { ous rate table of each category and annual rainfall data of the study area. Finally, the load distribution map of the } \\
\text { regional TP and total nitrogen was outputted by using ArcGIS. }\end{array}$ \\
\hline $\begin{array}{l}\text { Habitat quality } \\
\text { (remote } \\
\text { sensing } \\
\text { indicators) }\end{array}$ & $\begin{array}{l}\text { Habitat quality refers to a comprehensive system of physical, chemical and biological conditions on which organ- } \\
\text { isms depend for survival. This condition is greatly significant to ecosystem health. On the basis of remote sensing } \\
\text { data evaluation, habitat quality assessment and trade-off of ecosystem services (INVEST 3.2.0) model were used } \\
\text { to evaluate the habitat of the watershed. The calculation formula of the model is shown below. } \\
\qquad \mathrm{D}_{\mathrm{xj}}=\sum_{\mathrm{r}=1}^{\mathrm{R}} \sum_{\mathrm{y}=1}^{\mathrm{Y}_{\mathrm{r}}}\left(\frac{\mathrm{W}_{\mathrm{r}}}{\sum_{\mathrm{r}=1}^{\mathrm{R}} \mathrm{w}_{\mathrm{r}}}\right) \mathrm{r}_{\mathrm{y}} \mathrm{i}_{\mathrm{rxy}} \beta_{\mathrm{x}} \mathrm{S}_{\mathrm{jr}} \\
\mathrm{D}_{\mathrm{xj}} \text { : degree of habitat degradation. R: number of threat factors. } \mathrm{Y}_{\mathrm{r}} \text { : grid number set of threat factor grid layer. } \mathrm{W}_{\mathrm{r}} \text { : } \\
\text { weight of threat factors. } \mathrm{r}_{\mathrm{y}} \text { : number of threat factors on each grid of land use type layer. } \mathrm{i}_{\mathrm{rxy}} \text { : influence degree of } \\
\text { threat factors. } \beta_{\mathrm{x}} \text { : degree of legal protection (the degree of legal protection is assumed to be effective; thus, the } \\
\text { value is } 1) . \mathrm{S}_{\mathrm{jr}}: \text { sensitivity of land use types to threat factors. }\end{array}$ \\
\hline
\end{tabular}


B. Continued.

\begin{tabular}{|c|c|}
\hline & $\begin{array}{l}\text { Water conservation quantity refers to the comprehensive performance of multiple hydrological processes and } \\
\text { hydrological effects of the ecosystem, reflecting the ability of the ecosystem to retain precipitation or regulate river } \\
\text { runoff. The remote sensing data obtained through ArcGIS software analysis were calculated and analysed using the } \\
\text { tools of the corresponding modules. Through assignment, conversion and grid calculation, the water conservation } \\
\text { in the study area was finally calculated. The calculation formula is given below. } \\
\qquad \mathrm{W}_{\mathrm{i}}=\sum 10 \times \mathrm{A}_{\mathrm{i}} \times \mathrm{C}_{\mathrm{i}} \times \mathrm{P}_{\mathrm{i}} \times \alpha \times \beta \\
\mathrm{W}_{\mathrm{i}} \text { : Annual water conservation in the study area }\left(\mathrm{m}^{3}\right) \text {. } \mathrm{A}_{\mathrm{i}} \text { : area of land use type (hm2). } \mathrm{C}_{\mathrm{i}} \text { : Vegetation coverage. } \mathrm{P}_{\mathrm{i}} \text { : } \\
\text { Annual rainfall }(\mathrm{mm}) . \alpha \text { : Runoff coefficient. } \beta \text { : Development index. }\end{array}$ \\
\hline & $\begin{array}{l}\text { Ecological elasticity refers to the capacity of self-sustaining and regulating when the ecosystem is under certain } \\
\text { external environmental pressure, which represents the structural characteristics of the ecosystem. The calculation } \\
\text { formula is given below. } \\
\qquad \mathrm{ECO}_{\text {res }}=\sum_{\mathrm{i}=1}^{\mathrm{N}}\left(\mathrm{R}_{\mathrm{i}} \times \mathrm{D}_{\mathrm{i}}\right) \\
\mathrm{ECO}_{\text {res: }} \text { : ecological elasticity. } \mathrm{R}_{\mathrm{i}} \text { : proportion of the } i \text {-th type of land use. } \mathrm{D}_{\mathrm{i}} \text { : elastic score of the } i \text {-th land use type. } \mathrm{N} \text { : } \\
\text { number of land use types. }\end{array}$ \\
\hline & $\begin{array}{l}\text { River network density refers to the total length of main and tributaries per unit area, and is an important standard } \\
\text { of watershed structure and reflects the density of river system distribution in the watershed. Using DEM eleva- } \\
\text { tion data of study area, the river network is extracted by the hydrological analysis module of ArcGIS, and the total } \\
\text { length of the river channel is calculated to obtain the river network density. The calculation formula is given below. } \\
\qquad \mathrm{D}=\frac{\mathrm{L}}{\mathrm{A}} \\
\text { D: river network density. L: total length of the river channel in the watershed (km). A: watershed area }\left(\mathrm{km}^{2}\right) \text {. }\end{array}$ \\
\hline $\begin{array}{l}\text { Soil sensitivity } \\
\text { index }\end{array}$ & $\begin{array}{l}\text { Soil erosion sensitivity refers to the potential possibility and degree of soil eros } \\
\text { out considering human factors), indicating the sensitivity of ecosystem to huma } \\
\text { Soil Loss Equation (RUSLE) model was used to evaluate soil erosion sensitivit } \\
\qquad \mathrm{A}=\mathrm{LS} \times \mathrm{C} \times \mathrm{R} \times \mathrm{K} \times \mathrm{P} \\
\mathrm{A} \text { : average annual soil erosion }\left(\mathrm{t} \cdot \mathrm{km}^{-2} \cdot \mathrm{a}^{-1}\right), \mathrm{R} \text { : rainfall erosivity factor }(\mathrm{MJ} \cdot \mathrm{m} \\
\text { factor }\left(\mathrm{t} \cdot \mathrm{hm}^{2} \cdot \mathrm{h} \cdot \mathrm{MJ}^{-1} \cdot \mathrm{mm}^{-1} \cdot \mathrm{hm}^{-2}\right), \mathrm{LS} \text { : slope length factor, } \mathrm{C} \text { : vegetation cover a } \\
\text { water conservation measures factors; Ls, } \mathrm{C} \text { and } \mathrm{P} \text { are dimensionless factor } \\
\text { measure factor P has little relationship with natural system; thus, it is not cor } \\
\text { erosivity factor } \mathrm{R} \text {, soil erodibility factor } \mathrm{K} \text {, slope length factor } \mathrm{LS} \text { and vegetati } \\
\text { were selected to evaluate soil erosion sensitivi }\end{array}$ \\
\hline & $\begin{array}{l}\text { Population density refers to the average number of people per square kilometre of land area, which represents } \\
\text { the regional land carrying capacity. The population density of each evaluation unit was calculated by the formula, } \\
\text { and the spatial distribution map of population density in the study area was drawn by ArcGIS. The calculation } \\
\text { formula is given below. } \\
\qquad \mathrm{P}=\frac{\mathrm{n}}{\mathrm{S}_{\mathrm{z}}} \\
\text { P: population density, n: total population, Sz: evaluation area. }\end{array}$ \\
\hline $\begin{array}{c}\text { COD emissio } \\
\text { intensity }\end{array}$ & $\begin{array}{l}\text { COD emission intensity refers to the average emission of COD per square kilometre area, which represents } \\
\text { the degree of COD pollution in the evaluation area. The COD emission intensity of each evaluation unit was } \\
\text { calculated by the formula. ArcGIS was used to draw the spatial distribution map of COD emission intensity in the } \\
\text { study area. The calculation formula is given below. } \\
\qquad \mathrm{I}_{\mathrm{COD}}=\frac{\mathrm{P}_{\mathrm{COD}}}{\mathrm{S}_{\mathrm{z}}} \\
\qquad \mathrm{I}_{\mathrm{COD}} \text { : COD emission intensity, } \mathrm{P}_{\mathrm{COD}} \text { : COD emission intensity, } \mathrm{S}_{\mathrm{z}} \text { : evaluation area. }\end{array}$ \\
\hline $\begin{array}{l}\text { Ammonia } \\
\text { nitrogen } \\
\text { emission } \\
\text { intensity index }\end{array}$ & $\begin{array}{l}\text { Ammonia nitrogen emission intensity refers to the average annual ammonia nitrogen emission per square } \\
\text { kilometre area, which indicates the degree of ammonia nitrogen pollution in the evaluation area. The calculation } \\
\text { formula is given below. } \\
\qquad \mathrm{I}_{\mathrm{AN}}=\frac{\mathrm{P}_{\mathrm{AN}}}{\mathrm{S}_{\mathrm{z}}} \\
\mathrm{I}_{\mathrm{AN}} \text { : ammonia nitrogen emission intensity index, } \mathrm{P}_{\mathrm{AN}}: \text { ammonia nitrogen emission, Sz: evaluation area. }\end{array}$ \\
\hline $\begin{array}{l}\text { Sewage } \\
\text { discharge } \\
\text { intensity index }\end{array}$ & $\begin{array}{l}\text { Sewage discharge intensity refers to the average annual discharge of sewage (including domestic and industrial } \\
\text { sewage) per square kilometre area, indicating the degree of sewage pollution in the evaluation area. The sewage } \\
\text { discharge intensity of each evaluation unit was calculated, and the spatial distribution map of sewage discharge } \\
\text { intensity was drawn by ArcGIS. }\end{array}$ \\
\hline
\end{tabular}


B. Continued.

\begin{tabular}{|c|c|}
\hline WQI & $\begin{array}{l}\text { WQI refers to the quality of water, which reflects the water quality of the watershed by selecting multiple } \\
\text { indicators. The WQI was obtained by the comprehensive score of water quality evaluation. The water quality } \\
\text { evaluation scores of all sampling points in each evaluation unit were counted, and the mean values were obtained. } \\
\text { The alpine region has no sampling sites in the river due to the limitation of traffic conditions. However, } \\
\text { it represents the upstream of tributaries and has no pollution sources. The water quality of the river is equal to that } \\
\text { of the tributary region. }\end{array}$ \\
\hline $\begin{array}{l}\text { Connectivity } \\
\text { index }\end{array}$ & $\begin{array}{l}\text { The practical combination index } \gamma \text { and river network density } \mathrm{D} \text {, which are widely used, were selected to compre- } \\
\text { hensively evaluate the water system connectivity in the watershed. The calculation formula is given below. } \\
\qquad \gamma=\frac{\mathrm{L}}{3 \mathrm{~V}-2} \\
\text { L: actual number of river corridors per grid. V: number of nodes. } \gamma \text { : ratio of the actual number of river corridors } \\
\text { to the maximum possible number of river corridors. The larger values of } \gamma \text { and D indicate better connectivity of } \\
\text { drainage system. The mean value is used to evaluate the connectivity of the drainage system. }\end{array}$ \\
\hline $\begin{array}{l}\text { Environmental } \\
\text { governance } \\
\text { input index }\end{array}$ & $\begin{array}{l}\text { Investment in environmental governance refers to the investment in environmental protection and ecological } \\
\text { restoration. The higher value of the indicator indicates greater investment and governance intensity. The collected } \\
\text { information data were integrated, and the spatial distribution map of environmental governance investment was } \\
\text { drawn through ArcGIS. }\end{array}$ \\
\hline $\begin{array}{l}\text { Habitat quality } \\
\text { (Multi-source) }\end{array}$ & $\begin{array}{l}\text { Combined with the invest model and field investigation and monitoring, the overall habitat quality of the study } \\
\text { area was evaluated, and the overall and local habitat quality was comprehensively evaluated. The habitat quality } \\
\text { scores of all samples in the basic evaluation unit were calculated, and the mean values were considered the meas- } \\
\text { ured habitat quality scores of the evaluation unit. The high mountain area has no sampling point due to the limita- } \\
\text { tion of conditions, and the area has no industrial enterprises or livestock and poultry breeding industry. In addition, } \\
\text { the population density was small. Therefore, the final habitat quality of the high mountain area was obtained by } \\
\text { using the INVEST model. The other five evaluation units considered the measured habitat quality score, and the } \\
\text { average value of the habitat score was obtained through the INVEST model. }\end{array}$ \\
\hline
\end{tabular}

\section{Acknowledgement}

The authors are grateful to the Ecological Environment Bureau of Yongtai County for their generous assistance in data collection.

\section{Conflicts of Interest}

The authors declare no conflict of interest.

\section{References}

1. KARR J.R., DUDLEY D.R. Ecological perspective on water quality goals. Environmental Management, 5, 55, 1981.

2. VONDRACEK B., KOCH J.D., BECK M.W. A comparison of survey methods to evaluate macrophyte index of biotic integrity performance in Minnesota lakes. Ecological Indicators, 36, 178, 2014.

3. WU G., CAI Q.H. Expression as a whole of research content of the watershed. Acta Chimica Sinica, 18, 575, 1998.

4. COSTANZA R., MAGEAU M. What is a healthy ecosystem? Aquatic Ecology, 33, 105, 1999.

5. ZHANG H.Y., CAI Q.H., TANG T. Comprehensive assessment and comparison of lakes' ecosystem health in Erhai watershed. China Environmental Science, 32, 715, 2012.

6. WANG D.G., HU B.Q., FAN Y.H. Study on karst ecosystem health assessment in Chengjiang small watershed of Guangxi. Institute of Electrical and Electronics Engineers, 2012.
7. XU Y., GAO J.F., GAO Y.N. Spatial variation and dynamics of ecosystem health in the Taihu Lake watershed. Resources Science, 33, 201, 2011.

8. HAO L.X., SUN R.H., CHEN L.D. Health Assessment of River Ecosystem in Haihe River Basin,China. Huan Jing Ke Xue, 35, 3692, 2014.

9. CHEN Y.X., SHAO C.F., CHEN S.H. SDGs-Based River Health Assessment for Small- and Medium-Sized Watersheds. Sustainability, 12, 1846, 2020.

10. XU F., WANG Y.G., ZHANG N., WANG X., FAN Q. Health assessment of watershed ecosystems: The Chao river and Bai river basins as a case study. Shengtai Xuebao/ Acta Ecologica Sinica, 37, 932, 2017.

11. JIAO K.W., ZHOU Q.X. Health assessment of aquatic ecosystems in the Songhua River Basin on the basis of water quality and biological indicators. Chinese journal of ecology, 2015.

12. PATIL G.P., WAYNE L.M. Environmental and Ecological Health Assessment of Landscapes and Watersheds with Remote Sensing Data. Ecosyst Health, 5, 221, 2010.

13. KATARZYNA A.K., JAN K., ANNA M.M. Monitoring Cyanobacteria Blooms in Freshwater Lakes using Remote Sensing Methods. Polish Journal of Environmental Studies, 25, 27, 2016.

14. LIU G.J., WANG J.L., LI S.H., LI J., DUAN P. Dynamic Evaluation of Ecological Vulnerability in a Lake Watershed Based on RS and GIS Technology. Polish Journal of Environmental Studies, 28, 1785, 2019.

15. TANG T., STEVENSON R.J., GRACE J.B. The importance of natural versus human factors for ecological conditions of streams and rivers. Science of the Total Environment, 704, 2020.

16. HAZBAVI Z., SADEGHI S.H., GHOLAMALIFARD M., DAVUDIRAD A.A. Watershed health assessment 
using the pressure-state-response (PSR) framework. Land Degradation \& Development, 31, 3, 2020.

17. WASIUTA V., KIRK J.L., CHAMBERS P.A., ALEXANDER A.C., WYATT F.R., ROONEY R.C., COOKE C.A. Accumulating Mercury and Methylmercury Burdens in Watersheds Impacted by Oil Sands Pollution. Environmental Science \& Technology, 51, 12856, 2019.

18. ALEXANDER A.C., CHAMBERS P.A. Assessment of seven Canadian rivers in relation to stages in oil sands industrial development, 1972-2010. Environmental Reviews, 24, 484, 2016.

19. YANG X.L., ZHANG P.D., L, W.T. Evaluation of four seagrass species as early warning indicators for nitrogen overloading: Implications for eutrophic evaluation and ecosystem management. Science of the Total Environment, 635, 1132, 2018.

20. BALLESTER C., ZARCO-TEJADA P., NICOLÁS E., ALARCÓN J., FERERES E., INTRIGLIOLO D., GONZALEZ-DUGO V. Evaluating the performance of xanthophyll, chlorophyll and structure-sensitive spectral indices to detect water stress in five fruit tree species. Precision Agriculture, 19, 178, 2018.

21. HARGETT E.G., ZUMBERGE J.R., HAWKINS C.P. Development of a RIVPACS-type predictive model for bioassessment of wadeable streams in Wyoming. Ecological Indicators, 7, 807, 2007.

22. 22. Nichols S.J., Dyer F.J. Contribution of national bioassessment approaches for assessing ecological water security - an AUSRIVAS case study. Frontiers of Environmental Science - Engineering in China, 7, 669, 2013.

23. XU F.L., TAO S., DAWSON R.W. Lake ecosystem health assessment: indicators and methods. Water Resource, 35, 3157, 2001.

24. RAPPORT D.J., REGIER H.A., HUTCHSON T.C. Ecosystem behavior understress. American Naturalist, $\mathbf{1 2 5}, 617, \mathbf{1 9 8 5}$

25. KONG H.M., ZHAO J.Z., JI L.Z. Assessment method of ecosystem health. Journal of Applied Ecology, 13, 486, 2002.

26. VONDRACEK B., KOCH J.D., BECK M.W. A comparison of survey methods to evaluate macrophyte index of biotic integrity performance in Minnesota lakes. Ecological Indicators, 36, 178, 2014.

27. YODER C.O., RANKIN E.T. The Role of Biological Indicators in a State Water Quality Management Process. Environmental Monitoring And Assessment, 51, 61, 1998.

28. FRA_K M., BARYŁA A. Assessment of the state of water quality of the Dzierzgon Lake using chemical and biological indicators Land Reclamation. Annals of Warsaw University of Life Sciences, SGGW, 44, 111, 2013.

29. BAEK S.H., SON M., KIM D., CHOI H.W, KIM Y.O. Assessing the ecosystem health status of Korea Gw angyang and Jinhaebays based on aplanktonic index of biotic integrity (P-IBI). Ocean Science Journal, 49, 291, 2014.

30. VALDERMEULEN H. The development of marine indicators for coastalzone management. Ocean \& Coastal Management, 39, 63, 1998.

31. SUN C., CHEN W. Fuzzy comprehensive model based on combination weighting in watershed application of ecological health assessment. IOP Conference Series: Earth and Environmental Science, 227, 052009, 2019.

32. PATIL G.P., MYERST W.L. Environmental and ecological health assessment of landscapes and watersheds with remote sensing data. Ecosyst Health, 5, 221, 1999.
33. OANA M. Watershed Sustainability Index Development and Application: Case Study of the Motru River in Romania. Polish Journal of Environmental Studies, 26, 2095, 2017.

34. HAZBAVI Z., SADEGHI S.H., GHOLAMALIFARD M., DAVUDIRAD, A.A. Watershed health assessment using the pressure-state-response (PSR) framework. Land Degradation and Development, 2019.

35. NAUBI I., NARDARI N.H., SHARIF M.S., NURUL F.B.I., LAVANIA B. Effectiveness of Water Quality Index for Monitoring Malaysian River Water Quality. Polish Journal of Environmental Studies, 25, 231, 2016.

36. LEE S.J., AN K.G. Influence of Weir Construction on Chemical Water Quality, Physical Habitat, and Biological Integrity of Fish in the Geum River, South Korea. Polish Journal of Environmental Studies, 28, 2175, 2019.

37. DALU T., TAMBARA E., CHARI L.D., MOYO S., NHIWATIWA T. A test of the Lake Habitat Survey method in Cleveland Reservoir and Lake Chivero (Manyame River Basin, Zimbabwe). Water SA, 42, 102, 2016.

38. TALENT D.B., MUTHUKRISHNA V.K. Development of Water Quality Indices (WQIs): A Review. Polish Journal of Environmental Studies, 29, 2011, 2020.

39. JAYALAKSHMI S., VELAPPAN E. Assessment of Water Quality Index in the St. Thomas Mount Block Using GIS and Remote Sensing. Polish Journal of Environmental Studies, Polish Journal of Environmental Studies, 24, 1611, 2015.

40. YAN F., QIAO D.Y., QIAN B., MA L., XING X.G., ZHANG Y., WANG X.G. Improvement of CCME WQI using grey relational method. Journal of Hydrology, 543, 316,2016

41. HAIDER H., ALKHOWAITER M.H., SHAFIQUZZAMAN M., ALSALEEM S.S., ALMOSHAOGEH M., ALHARBI F. Spatiotemporal Water Quality Variations in Smaller Water Supply Systems: Using Modified CCME WQI from Groundwater Source to Distribution Networks. Water, 11, 1884, 2019.

42. ENAD H.Y., JAEEL A.J. Water quality index of Tigris River on Waist Governorate for aquatic life. IOP Conference Series Materials Science and Engineering, 584, 012029, 2019.

43. LIAO H., SARVER E., KROMETIS L.A.H. Interactive effects of water quality, physical habitat, and watershed anthropogenic activities on stream ecosystem health. Water Research, 2018.

44. FLINT N., ROLFE J., JONES C.E., SELlENS C., JOHNSTON N.D., UKKOLA L. An Ecosystem Health Index for a large and variable river basin: Methodology, challenges and continuous improvement in Queensland's Fitzroy Basin. Ecological Indicators, 73, 2016.

45. CAO Y.Q., CHEN Y.Z., ZHENG M. The biological function of rabbit blastocyst peptides(RPBs). Science China-Chemistry, 34, 64, 1991.

46. KIM J.H., OH H.M., KIM I.S., LIM B.J. Ecological Health Assessments of an Urban Lotic Ecosystem Using a Multimetric Model along with Physical Habitat and Chemical Water Quality Assessments. International Journal of Environmental Research, 7, 659, 2013.

47. BONADA N., DALLAS H., RIERADEVALL M., PRAT N. A comparison of rapid bioassessment protocols used in 2 regions with Mediterranean climates, the Iberian Peninsula and South Africa. Journal of The North American Benthological Society, 25, 487, 2006.

48. HWANG Y.S., SEO M., LEE B.R., LEE H.J., PARK Y.H., KIM S.K., LEE H.C., CHOI H.J., YOON J., KIM 
H., HAN J.Y. The transcriptome of early chicken embryo reveal signaling pathways governing rapid asymmetric cellularization and lineage segregation. Development, 145, 2018.

49. LADSON A.R., WHITE L.J., DOOLAN J.A., FINLAYSON B.L. Development and Testing of an Index of Stream Condition for Waterway Management in Australia. Freshwater Biology, 41, 453, 1999.

50. OFORI-ATTA A.M.L., LINDEN W. The effect of social change on causal beliefs of mental disorders and treatment preferences in Ghana. Social Science \& Medicine, 40, 1231, 1995.
51. WANG K., LI N., YU X. Eco-environmental carrying capacity evaluation index system based on the concept of P-S-R model-A case study in Shandong Peninsula. Acta Scien Circum, 34, 2133, 2014.

52. LIU D., HAO S. Ecosystem Health Assessment at CountyScale Using the Pressure-State-Response Framework on the Loess Plateau, China. International Journal of Environmental Research \& Public Health, , 14, 2016.

53. ZHAO Y.W., ZHOU L.Q., DONG B.Q., DAI C. Health assessment for urban rivers based on the pressure, state and response framework-A case study of the Shiwuli River. Ecological indicators, 99, 324, 2019. 